\title{
MOBILITY OF STUDENTS AND THE FINANCIAL SUSTAINABILITY OF HIGHER EDUCATION SYSTEMS IN THE EU: A UNION OF HARMONY OR IRRECONCILABLE DIFFERENCES?
}

\author{
Alexander Hoogenboom*
}

\begin{abstract}
Summary: The purpose of this contribution is to explore the apparent conflict between the promotion of student mobility on the one hand and the interests of the Member States in ensuring the (financial) sustainability of their higher education system on the other. To this end, the paper is divided into three parts. The first part presents an overview and analysis of the legal principles applying to student mobility developed by the Court of Justice in its case law. The second part explores and analyses both sides of the debate as to whether Member States should be able to invoke budgetary concerns as ground for justification for a restriction of the rights of mobile students set out in the first part. The third part finally argues that as a general principle, such unilateral attempts at restriction by the Member State should be rejected but that at the same time there is cause to take the concerns of these Member States seriously. In the end, it is suggested that a multilateral approach at EU level is perhaps the only solution capable of addressing the conflict.
\end{abstract}

\section{Introduction}

The mobility of students in the European Union is a phenomenon of ever-increasing importance in the EU, with more than half a million EU students choosing to study in an EU Member State different from their nationality for part of their studies or for full courses abroad. This represents an increase in mobile students of about $50 \%$ in comparison to $2000 .^{1}$ These migration flows have been strongly stimulated by the increasing support for this type of cross-border movement by policy makers at national and EU/European level ${ }^{2}$ as well as by the case law of the

\footnotetext{
${ }^{*}$ PhD researcher at the Faculty of Law, Maastricht University, and Visiting Fellow at the Faculty of Law, University of Western Australia.

1 Commission Staff Working Document SEC (2011) 'Progress Towards the Common European Objectives in Education and Training (2010/2011): Indicators and Benchmarks' 33-40.

2 For an overview of the Bologna process, see European Higher Education Area website 2010-2020 <http://www.ehea.info/> accessed 2 November 2013. At the EU level: Commission, Promoting the Learning Mobility of Young People (Green Paper) COM(2009) 329 final; and European Parliament Resolution of 23 September 2008 on the Bologna Process and
} 
Court of Justice. At the same time, however, the recent series of cases assessing the lawfulness of residence requirements designed to curb the influx of foreign students, or to delimit the circle of beneficiaries of portable study grants, shows that Member States have increasingly become concerned about the financial consequences of such mobility.

This paper seeks to explore this apparent conflict between the promotion of student mobility on the one hand and the interests of the Member States in ensuring the (financial) sustainability of their higher education system on the other. First, it will provide an overview of the legal principles developed by the Court in its case law and discuss recent developments therein based on three themes: access to higher education, equal treatment as regards study facilitating benefits in the host State, and the export of study grants from the home State. The second part will seek to provide context to and analyse both sides of the recent debate as to whether Member States can invoke budgetary concerns, in particular in the light in the context of the economic crisis, as a ground for justification for restrictions imposed on the mobility of students. The third part will ultimately argue that as a general principle attempts at justification on economic grounds should be rejected in view of the strong (economic) benefits attached to such mobility. At the same time, however, the 'one size fits all' nature of the legal principles developed by the Court has a differential impact on the Member States of the EU. This has the consequence that some Member States, in a relative sense, contribute to a much greater extent to the public good of student mobility than others. Given the current tension between the aims of student mobility and the financial sustainability of domestic higher education systems, it is suggested that a multilateral approach at EU level may perhaps be the only solution capable of reconciling the aims by fairly distributing the (financial) responsibilities of the Member States.

\section{EU law and the mobility of students}

There is a relatively long history in the jurisprudence of the Court of the student with a nationality of one of the Member States crossing borders in search of (post-secondary) education. ${ }^{3}$ With a view to categorising the extensive case law of the Court in this regard, two distinct legal regimes can be discerned at the summa divisio level: cases involving a claim by an EU citizen of equal treatment to the nationals of the host Member State as regards access to education, and cases involving equal treatment

Mobility (2008/2070(INI)), OJ (2010) C8 E/18. Moreover, consider that at the national level some 24 Member State offer some form of portable study allowances.

3 Starting nearly 40 years ago with Case 9/74 Casagrande $v$ Landeshauptstadt München [1974] ECR 773. 
as regards the conditions under which the rights of free movement of students are exercised. ${ }^{4}$

This division has its origins in a set of cases decided in the 1980s and involved the scope ratione materiae of what is now Article 18 TFEU. Whereas the conditions of access to vocational training were held to fall within the scope of the then Article 7 EEC (linked as it was with the free movement of workers and the competence of the EEC to foster the establishment of a common vocational policy), ${ }^{5}$ maintenance aid in the form of study grants were considered a matter of social/educational policy belonging to the Member States. It followed that the latter, 'at the current stage of development of EC law', fell outside the scope of that Article. ${ }^{6}$ This distinction was maintained for a period of 17 years until the seminal case of Bidar. $^{7}$ In that case, the Court departed from its older case law and held that in the light of the introduction of EU citizenship and the new (albeit limited) EC competences in the area of education, study grants could now properly be seen as falling within the scope of the Treaty for the purposes of the then Article 12 TEC. ${ }^{8}$

While the two regimes were thus put on the same footing, it will nevertheless be shown below that the legacy of the original distinction continues to have consequences today: if a measure is considered to affect 'access to education', the Court will subject it to a more rigorous scrutiny than when it concerns study facilitating benefits, where the approach of the Court is more hands-off. This division also resonates more generally within the internal market: ${ }^{9}$ measures that impede access 'at the gate' are usually treated more harshly than those that apply to and modify the conditions under which free movement rights are exercised. ${ }^{10}$ One could compare the issue with the free movement of goods: measures strongly and directly impeding access, such as quantitative restrictions and cu-

\footnotetext{
$4 \quad$ This distinction was already noted at an early stage by AG Slynn in his Opinion delivered on 28 June 1988 in Case C-42/87 Commission v Belgium [1988] ECR 5445. See also AG Sharpston in her Opinion delivered on 25 June 2009 in Case C-73/08 Bressol [2010] ECR I-2735, paras 80ff (emphasis added).

5 Case 293/83 Françoise Gravierv City of Liège [1985] ECR 593, paras $18 \mathrm{ff}$.

6 Case 39/86 Sylvie Lairv Universität Hannover [1988] ECR 3161, para 15.

7 Case C-209/03 The Queen, on application of Dany Bidar $v$ London Borough of Ealing and Secretary of State for Education and Skills [2005] ECR I-2119. See also Case C-184/99 Rudy Grzelczyk $v$ Centre public d'aide sociale d'Ottignies-Louvain-la-Neuve [2001] ECR I-6193, paras $34 \mathrm{ff}$.

8 Bidar (n 7), paras 30-42.

9 See also the distinction made in Regulation 492/2011 between chapter 1 , section 1 , which concerns access to employment, and chapter 1 , section 2 , which deals with equal treatment as regards the conditions of employment. See further the Opinion of AG Lenz in Case C-415/93 Bosman [1995] ECR I-4921, in particular para 210.

10 The more serious the infringement, the stricter the proportionality test conducted by the Court and vice versa: J Jans, 'Proportionality Revisited' (2000) 27(3) Legal Issues of Economic Integration 239, 264.
} 
stom duties ${ }^{11}$ in the strict sense, are deemed to go to the very heart of the operation of the internal market. As a result, the former only allows for limited derogations, ${ }^{12}$ whereas the latter are prohibited outright. Where, however, it concerns measures which apply 'within' the Member States, modifying the conditions under which goods are sold, such as the Keck 'Certain Selling Arrangements'13 and the internal taxation regime under Article 110 TFEU, the discretion of the Member States is greater (and the test applied by the Court more lenient). ${ }^{14}$

Similarly, where a Member State seeks to impede access to education by foreign EU nationals (the 'very essence of the principle of freedom of movement for students'15) by imposing higher tuition fees than apply for domestic students ${ }^{16}$ or quantitative restrictions such as those at issue in Bressol, ${ }^{17}$ we see that the former have always been prohibited outright, while the latter are only allowed in very exceptional circumstances. In contrast, where it concerns equal treatment as regards study facilitating benefits (which modify the conditions under which free movement rights of students are exercised), the freedom granted to the Member State to restrict eligibility for such grants is greater. ${ }^{18}$ At the same time, this distinction should, of course, not be taken too strictly: denial of a certain benefit (eg a study grant) may cast its shadow before it and discourage the student from exercising his or her free movement at all, thus impeding the student's access to education abroad. ${ }^{19}$ Nevertheless, it is submitted that a certain localisation on a scale ranging from measures that impact on enrolment versus measures further removed from access and towards conditions under which free movement is exercised does take place, as will be seen below.

\subsection{Access to education}

The main rule in this regard is that any EU citizen exercising his or her free movement rights as enshrined in Article 21 TFEU can rely

\footnotetext{
11 As well as CEEs which by definition only apply to 'border measures', see Article 30 TFEU and Case 24/68 Commission v Italy [1969] ECR 193.

12 See Article 36 TFEU.

13 Joined cases C-267/91 and C-268/91 Keck and Mithouard [1993] ECR I-6097.

14 See generally, C Barnard, The Substantive Law of the EU: The Four Freedoms (OUP 2013) ch 3, 5; and H-G Kamann, 'Artikel 110 AEUW' in R. Streinz (ed), EUV/AEUV (Verlag CH Beck 2012) 1431-1436.

15 Case C-147/03 Commission v Austria (diploma requirements) [2005] ECR I-5969, para 70.

16 Gravier (n 5).

17 Case C-73/08 Nicolas Bressol and Others $v$ Gouvernement de la Communaute francaise [2010] ECR I-2735.

18 See below.

19 This has led Snell to argue that the distinction is normatively and conceptually fallacious: J Snell, 'The Notion of Market Access: A Concept or Slogan?' (2010) 47 CML Rev 437, 443-446.
} 
on Article 18 TFEU to claim equal treatment concerning the conditions of access to education. ${ }^{20}$ This equal treatment right is a strong one and militates against restrictions of various kinds ranging from differential tuition fees to discriminatory diploma requirements. Attempts at justification of these restrictions by the Member State are normally treated harshly and are rejected.

\subsubsection{Scope ratione materiae I: vocational training or education?}

Historically, the Court has always referred to equal treatment as regards the conditions of access to 'vocational training'. This concept was first developed in Gravier, and its emergence in the legal dictionary of the Court can largely be explained by the latter's attempt to imbue its ruling in that case with a degree of legitimacy. The context of the Gravier case was that of a European Economic Community in which rights of free movement and equal treatment were primarily granted to market citizens (with some derivative rights for family members): individuals with the nationality of one of the Member States who sought to pursue an economic activity in the host Member State. Françoise Gravier, however, was a French national and a 'pure student': she sought to cross borders solely for the purpose of studying in the host State. It was thus not immediately clear why she should be able to rely on Article 7 EEC to challenge the fee system that Belgium had imposed which discriminated on grounds of nationality. However, then Article 128 EEC referred to the competence of the EEC to establish a 'common vocational policy', which in the eyes of the Court clearly brought issues regarding access to such vocational training within the scope of EEC law for the purposes of applying the principle of non-discrimination on grounds of nationality. ${ }^{21}$ This did mean, however, that the Court was 'stuck' with this concept of vocational training. This was overcome, however, by a broad definition of that concept:

any form of education which prepares for a qualification for a particular profession, trade or employment or which provides the necessary training and skills for such a profession, trade or employment is vocational training, (...). ${ }^{22}$

In Blaizot, the Court confirmed that 'vocational training' was truly a Union concept which defied national classifications ${ }^{23}$ and included in general also 'academic' or higher education provided in university institutes as these provide the knowledge or skills an individual might need in the exercise of a profession. However, courses intended solely to improve

\footnotetext{
20 Bressol (n 17) paras 30-32.

21 In addition to the links between the mobility of students and the free movement of workers, see Gravier (n 5) para $20 \mathrm{ff}$.

22 ibid para 30.

23 Case 24/86 Vincent Blaizot v University of Liège and others [1988] ECR 379, paras 15-21.
} 
the general knowledge of participants rather than preparing them for the pursuit of a particular occupation were excluded from this concept. ${ }^{24}$ In addition, Humbel suggests that at least primary education is excluded from the concept and that concerning secondary education regard must be had to whether the instruction, taken as an indivisible whole, also includes elements preparing the pupil for a particular trade, profession or employment - if not, secondary education will not constitute 'vocational training'. ${ }^{25}$

It would follow from the forgoing that primary, secondary and tertiary education lacking an economic nexus (preparation for a trade/profession) fall outside the scope of Article 18 TFEU, allowing therefore Member States to maintain, for example, an enrolment fee system, discriminating against migrant EU nationals for such courses. At the same time, the issue has not been revisited recently. It is arguable that for the reasons already mentioned by the Court in Bidar, namely the introduction of EU citizenship and the attendant free movement rights (thereby moving beyond the economic nexus) and the creation of the (limited) competences of the EU covering education more generally, ${ }^{26}$ the scope of Article 18 TFEU goes beyond vocational training and also covers equal treatment as regards education in a general sense. ${ }^{27}$ There is support for this interpretation in Bressol, where the Court refers, in general, to the obligation of the Member States to have due regard to Union law, and in particular the free movement provisions and the principle of non-discrimination on grounds of nationality, when organising their education systems and vocational training ${ }^{28}$ (the obligation thus applying to both separately). ${ }^{29}$

\subsubsection{Scope ratione materiae II: conditions of access to education}

The second aspect to be considered is the breadth of the principle of equal treatment in terms of the measures enacted by the Member States it catches. The cases of Gravier and Forcheri confirm that the imposition

\footnotetext{
24 ibid para. 20.

25 Case 263/86 Belgian State v René Humbel and Marie-Thérèse Edel [1988] ECR 5365, paras 8-13, 22-25.

26 See current Articles 165 and 166 TFEU, as well as Article 9 TFEU.

27 It should be noted that EU workers and their family members, on the basis of Article $7(2)$ and 10 of Regulation 492/2011, in any case enjoy a right of equal treatment with regard to all forms of education: Humbel (n 25) para. 24. See further: A-P van der Mei, Free Movement of Persons in the European Community: Cross-Border Access to Public Benefits (Hart Publishing 2003) 349, 375.

28 Bressol (n 17) para 28-29.

29 See further $\mathrm{H}$ van Eijken, 'Zijn er nog grenzen aan gelijkheid? - De spanning tussen gelijke behandeling van Unieburgers versus de bevoegdheidsverdeling tussen de Unie en lidstaten' (2010) 6 Nederlands Tijdschrift voor Europees Recht 181, who discusses the tension between the principle of equal treatment and the (remaining) discretion of the Member States in organising their (higher) education systems.
} 
of higher tuition fees for migrant EU nationals than host Member State nationals constitutes a violation of Article 18 TFEU. ${ }^{30}$ Moreover, creative Member States seeking to introduce a practice whereby discriminatory tuition fees on the 'demand side' (student side) are removed, but are nevertheless enforced on the supply side (the educational establishment), are equally in breach of that Article: in response to Gravier, Belgium equalised the tuition fees, but at the same time adopted a practice in which it relegated most categories of foreign students to the category of 'non-funded student' when a certain extremely limited threshold was reached. ${ }^{31}$ This effectively forced educational establishments to exclude such foreign students or risk being underfunded. ${ }^{32}$ The Court held that this construction, in essence, had the same exclusionary effect as the original discriminatory tuition fees assessed in Gravier and found a violation of what is now Article 18 TFEU. ${ }^{33}$ In Brown, a final variant was considered by the Court: in Scotland, all students were required to pay a tuition fee but the devolved authority (selectively) reimbursed (in full or in part) that fee through its study grant system. The Court ruled that such contributions did not constitute maintenance aid (at the time still excluded from Article 18 TFEU) and thus had to be provided to migrant EU nationals under conditions that did not discriminate on grounds of nationality. ${ }^{34}$

But the concept goes further than this. In Commission v Austria (diploma requirements), Austria had introduced an access condition tied to the secondary education diploma qualifying the student for university education: in order to gain access to a course of study offered at a university established in Austria, the student had to show that he or she fulfilled any special admission criteria for the same course of study in the Member State in which he or she had obtained his or her secondary education diploma. It followed, for example, that German nationals who did not manage to get a place to study medicine in Germany due to the operation of the numerus clausus were also barred from studying medicine in Austria. As such, Austria sought to rely on a form of the principle of mutual recognition in the context of recognition of diplomas for academic purposes, a policy area which moreover fell outside the scope of the Treaties (or so Austria submitted). The Court nevertheless held this to constitute an 'access condition' which could be examined for compatibility

30 Gravier (n 5) para 26 and Case 152/82 Forcheri [1983] ECR 2323, paras 17-18.

31 Funding would not be provided for those foreign students in excess of $2 \%$ of the Belgian students who were included for the purposes of determining the funding of the educational establishment in the previous academic year: Commission v Belgium (n 4) para 3.

32 ibid para 8 .

33 ibid paras 8-9.

34 Case 197/86 Steven Malcolm Brown v The Secretary of State for Scotland [1988] ECR 3205, para 15-17; Case C-357/89 VJM Raulin v Minister van Onderwijs en Wetenschappen [1992] ECR I-1027, para 34. 
with Article 18 TFEU. ${ }^{35}$

Finally, in the case of Bressol, the French Community of Belgium sought to limit the places available for non-resident students for a set of nine (para)medical and veterinary courses, in effect seeking to reserve study places for the domestic population. These quotas were also considered for compatibility with Article 18 TFEU. ${ }^{36}$

Overall, therefore, the Court seems to adhere to a broad concept of 'conditions of access' that will be considered for compatibility with EU law: any measure that impedes enrolment into a course or otherwise impedes the acquisition of student status will be caught (and, as will be seen, will be subjected to rigorous examination by the Court). ${ }^{37}$ As such, few measures will escape its grasp.

\subsubsection{Scope ratione personae}

Thirdly, it should be mentioned that the scope ratione personae is equally broad: any EU citizen can invoke these equal treatment rights and no distinction in the 'strength' of the claim of equal treatment is made based on whether the EU citizen is economically active or not (unlike under the regime to be discussed below). ${ }^{38}$

\subsubsection{Equal treatment and the scope for justification}

As a fourth and final point, a few words are needed on the attempts of the Member States seeking to justify infringements to the principle of equal treatment as regards the conditions of access to education. Looking at the relevant cases, ${ }^{39}$ it seems fair to conclude that the ECJ seems to take a very dim view of Member States' attempts to derogate from or justify their breach of equal treatment where it concerns access to education. As seen above, the ECJ has underlined that the opportunity for EU students to access higher education in other Member States constitutes the very essence of the free movement of students in the European Union. ${ }^{40}$ Limitations thereto can only be accepted exceptionally. ${ }^{41}$ This is further borne out by the fact that, apart from in the specific circum-

\footnotetext{
35 Commission v Austria (n 15) paras 31-35.

36 Bressol (n 17) para 28ff.

37 See also Raulin (n 34) para 34: 'right to equality of treatment regarding the conditions of access to vocational training applies (...) [to] any measure that may prevent the exercise of that right'.

38 Bressol (n 17) para 30-32.

39 Forcheri (n 30); Gravier (n 5); Blaizot (n 23); Commission v Belgium (n 4); Humbel (n 25); Case C-65/03 Commission v Belgium (diploma requirements) [2005] ECR I-6427; Commission v Austria (n 15); and Bressol (n 17).

$40 \quad$ Bressol (n 17) para 79.

41 ibid.
} 
stances of the Bressol case, the Court has never upheld any of the justifications relied upon by the Member States seeking to restrict access of migrant EU nationals. This hostility goes hand in glove with the fact that Member States do not seem overly concerned to put forward serious attempts at justification, ${ }^{42}$ and in particular lack evidence to substantiate their disparate claims. ${ }^{43}$ This is in particular illustrated by Commission $v$ Austria (diploma requirements) in which Austria only presented some rough estimates for specific courses of medicinal studies in defence of its generally applicable diploma requirement. ${ }^{44}$

The strict approach of the Court was also noticeable in Bressol. Belgium sought to rely, in its defence of quotas allocating places on the basis of whether the individual fulfilled certain residency requirements, on the necessity of the measure to combat pressure on the education budgets caused by the influx of foreign students, the deterioration of the quality of the higher education system as a result of overcrowding, and the threat posed to the maintenance of a high quality healthcare system. The Court, in the end, rejected the financing justification as unfounded ${ }^{45}$ and focused on the arguments relating to the maintenance of a high quality healthcare system. ${ }^{46}$ Belgium submitted that non-resident students crowding out resident students in (para)medical courses offered by the educational institutes was likely to lead to a shortage of healthcare professionals in the future (implicitly arguing that resident students were more likely to stay and take up employment in the French Community afterwards). The Court accepted that these concerns could not a priori be ruled out, but warned that the link between the maintenance of a high quality healthcare system and the education of future healthcare professionals was uncertain and somewhat hypothetical in nature. ${ }^{47}$ It then proceeded to lay out an extensive set of evidentiary requirements to establish whether the alleged risk to the public health system was in fact genuine: the national authorities were to furnish the referring court with a comprehensive analysis as to available study places, the (future) need for healthcare professionals, and the impact of possible correcting factors (eg the movement of health professionals to Belgium should a shortage arise, as well as the probability of graduates in Belgium nevertheless le-

\footnotetext{
42 Consider, for example, Belgium which until Bressol had failed to submit any justifications for consideration to the Court: see Gravier (n 5); Commission v Belgium (n 4) para 6; Case C-47/93 Commission v Belgium [1994] ECR I-1593, para 9; and Commission v Belgium (diploma requirements) (n 39) para 30.

43 This seems to be a recurring issue before the Court: N Niamh Shuibhne, 'Annotation of Schwarz, Commission v. Germany and Morgan' (2008) 45 CML Rev, 771, 781-786.

44 Commission v Austria (n 15), paras 61-65 and in particular para 63.

45 Bressol (n 17) paras 49-51.

46 ibid paras 52-54, $62 \mathrm{ff}$.

47 ibid, para 69.
} 
aving for jobs abroad). ${ }^{48}$ Moreover, even where such genuine risks were established, the Court admonished the national court to carefully examine compliance with the principle of proportionality, bearing in mind the importance of the principle of access to higher education as the essence of the free movement of students, and that any incursion thereupon should remain strictly limited. ${ }^{49}$ As such, whatever the outcome, sufficiently wide access to higher education by migrant EU students had to be safeguarded. ${ }^{50}$

It seems, therefore, that Bressol rather confirms the rule of respect for equal treatment as regards the conditions of access to education: only in very exceptional circumstances, probably limited to the specific factual situation of the French Community of Belgium and possibly Austria, ${ }^{51}$ and limited primarily to (para)medical studies, will a restriction of that principle be accepted. Consider further that the evidentiary barrier is high: the Belgian Constitutional Court in the end only accepted the lawfulness of the quota for three courses, holding that for the other studies Belgium had failed to adduce sufficient evidence. ${ }^{52}$ The scope for the justification of restrictions in this regard is thus very narrow ${ }^{53}$ and, even where successful, Bressol suggests that some boundaries cannot be crossed: at the end of the day, the principle of equal treatment with host Member State nationals as regards access to education cannot be a hollow one.

\subsection{Conditions under which the free movement of students are exer- cised: study facilitating benefits}

The legal regime governing access of migrant EU nationals to study facilitating measures offered by Member States is somewhat more differentiated in nature. Since Bidar, the main principle here is that individuals have the right to equal treatment with host Member State nationals

\footnotetext{
48 ibid paras 70-73.

49 ibid paras 75-79.

50 ibid.

51 See for some background information of the situation of Austria and Belgium in this regard S Garben, 'Case note on 73/08, Bressol, [2010]' (2010) 47 CML Rev 1493, 1495-1499, 1504.

52 Constitutional Court (Belgium) No 89/2011 of 31 May 2011, reference number 4034 and 4093, paras B.8.1 - B.8.8.5 (concerning the bachelor in veterinary sciences and bachelor physiotherapy and physiotherapy and rehabilitation).

53 See also A-P van der Mei, 'Free Movement of Students and the Protection of National Educational Interests: Reflections on Bressol and Chaverot' (2011) 13 European Journal of Migration and Law 123, 130-133. Consider also that the Commission is actively monitoring the measures adopted by Belgium and Austria and at present still seems unconvinced that the evidentiary requirements laid down by the ECJ in Bressol have been satisfied: Commission, 'Austria and Belgium Given More Time to Justify Quotas' (Press releases database IP/12/1388, 18 December 2012) < http://europa.eu/rapid/press-release_IP-121388_en.htm> accessed 31 December 2013.
} 
as regards eligibility for study facilitating benefits ${ }^{54}$ (such as maintenance aid in the form of study grants and loans or student travel concessions), but the host Member State may limit its duty to show financial solidarity with the nationals of other Member States in this regard by only providing such benefits to those individuals having demonstrated a certain degree of integration with (the society of) the host Member State.

\subsubsection{Scope ratione materiae: study facilitating benefits}

This category is very much evolving in the case law of the Court and still somewhat undefined. Since Bidar, overturning the Court's judgment in Lair and Brown, it is clear that maintenance aid in the form of study grants or other forms of (subsidised) loans for study purposes fall within the scope of Article 18 TFEU. The recent judgment Commission v Austria (student travel concessions) confirms that (state financed) travel concessions or accommodation for students also fall within this legal regime (rather than, for example, the access regime discussed above), but as will be seen below, must be distinguished from study grants and loans in terms of the integration requirements a Member State can impose on the student. Neither category has, as such, been defined by the Court, although the Court seems keen on keeping the category 'study grants or loans' as narrow as possible. ${ }^{55}$ It remains to be seen how other forms of student benefits (or the allowances students are eligible for) are qualified in this regard (as 'study grants', or as sui generis benefits): some Member States ${ }^{56}$ provide book or food allowances, special student housing, or other special grants (eg to reimburse students paying for mandatory health insurance policies). ${ }^{57}$

2.2.2 Who can access study grants in the host Member State I: the EU citizen as 'pure student'

On the one hand, there are EU citizens who leave their Member State of origin to study in another Member State, with no further connections with the host State: the 'pure student' mentioned above. These individuals, while in principle eligible for equal treatment with regard to study facilitating benefits, can be required to provide proof of a certain degree of integration with the host State before such benefits are provided.

\footnotetext{
54 This should in principle also include study loans by private lenders where these are backed by the Member State such as provided for, eg, in Finland. See Articles 15-16 Opintotukilaki 1994/65.

55 Case C-75/11 Commission v Austria (student travel concessions) [2012] (nyr) paras 53-56.

56 See for an overview of the different systems of the $27 \mathrm{Member}$ States and the different benefits they provide students: P Minderhoud, Study Grants in the EU,(European Network on Free Movement of Workers: Radboud Universiteit Nijmegen, 2012) on file with the author. 57 See Commission, 'Youth on the Move: A Guide to the Rights of Mobile Students in the European Union' (Communication) COM(2010) 477 final 9-11.
} 
Concerning maintenance aid provided in the form of study grants and loans, in Förster ${ }^{58}$ the Court upheld and found proportional the imposition of a durational residence requirement requiring the migrant EU student to have resided in the Netherlands for five years prior to being provided with study finance under the Wet studiefinanciering 2000. ${ }^{59}$ As such, the Court ostensibly harmonised its position with that taken by the EU legislator in the Citizen's Rights Directive (CRD): ${ }^{60}$ Article 24(2) of that Directive provides an exception to the principle of equal treatment with host Member State nationals formulated in Article 24(1) for maintenance aid for studies, providing that Member States only have to provide such grants to individuals having obtained a right to permanent residence (normally obtained after five years of lawful residence, see Article 16 CRD). ${ }^{61}$ Thus, Member States can, as the outer limit, impose a five-year residence requirement prior to providing migrant EU students with study grants or loans under their respective systems.

At the same time, it may very well be questioned whether the strict reliance on, and application of, a durational residence requirement as a means to assess a genuine link is still good law. A body of case law of the Court seems to be developing which, it is submitted here, requires Member States to engage in a more wide-ranging inquiry into the degree of integration of the individual with the host State. In D'Hoop, ${ }^{62}$ ruled in 2002, the Court held that:

However, a single condition concerning the place where the diploma of completion of secondary education was obtained is too general and exclusive in nature. It unduly favours an element which is not necessarily representative of the real and effective degree of connection between the applicant for the tideover allowance and the geographic employment market, to the exclusion of all other representative elements. It therefore goes beyond what is necessary to attain the objective pursued. ${ }^{63}$

\footnotetext{
58 Case C-158/07 Jacqueline Förster v Hoofddirectie van de Informatie Beheer Groep [2008] ECR I-8507.

59 ibid paras 45-58.

60 Directive 2004/38/EC of the European Parliament and of the Council of 29 April 2004 on the right of citizens of the Union and their family members to move and reside freely within the territory of the Member States [2004] OJ L158/77. See also O Golynker, 'Case Note on Case C-158/07, Jacqueline Förster v Hoofddirectie van de Informatie Beheer Groep, Judgment of the Court (Grand Chamber) of 18 November 2008, not yet reported', (2009) 46 CML Rev 2021, 2024-2026.

61 As will be seen below and recognised in Article 24(2) CRD, EU citizens who are workers and their family members cannot be made subject to this residence requirement.

62 Case C-224/98 Marie-Nathalie D'Hoop v Office national de l'emploi [2002] ECR I-6191.

63 ibid para 39 (emphasis added).
} 
More recently, in Stewart, ${ }^{64}$ the applicant was denied a short-term incapacity benefit in youth inter alia because she had not resided in Great Britain for at least 26 weeks in the 52 weeks immediately preceding the claim. The Court ruled that while that requirement, as such, was not unreasonable, it was nevertheless too exclusive in nature as it disregarded other elements attaching Stewart to the UK. ${ }^{65}$ Similarly, in Commission $v$ the Netherlands (export of study grants), the Court condemned the imposition of the requirement to have resided in the Netherlands for at least three years in the six years preceding an application for export study finance for a course of study abroad as being 'too exclusive'. ${ }^{66}$ This trend is strongly confirmed in the recent export of study grant cases, to be discussed below.

It would seem to follow that sole reliance on a single genuine link indicator is increasingly becoming a highly questionable practice; ${ }^{67}$ rather, the Court is increasingly insisting on a more individual assessment of the circumstances to determine the 'real and effective degree of connection'. ${ }^{68}$ At the same time, it is recognised here that forcing administrative authorities to engage in fully individual assessments, taking into account all elements of their integration, may put a great strain on their resources. ${ }^{69}$ More importantly, lack of clear and transparent criteria for the assessment of genuine links, in particular in the context of the sometimes muddy waters of administrative practice, may undermine legal certainty and result in less awareness of EU citizens of the rights they may be able to legitimately claim in a foreign Member State. ${ }^{70}$

Consider the current example of Austria, in which the Studienförderungsgesetz 1992 provides in Article 4(1) that migrant EU nationals will be granted Austrian study grants where such is required by EU law (a 'catch-all' clause). Such a clause handily saves the legislator from having

\footnotetext{
64 Case C-503/09 Lucy Stewart v Secretary of State for Work and Pensions [2011] (nyr).

65 ibid para 95.

66 Case C-542/09 Commission $v$ the Netherlands [2012] (nyr) para 86.

67 See further: Case C-367/11 Déborah Prete $v$ Office national de l'emploi [2012] (nyr) para 31; Joined Cases C-11/06 and C-12/06 Rhiannon Morgan v Bezirksregierung Köln and Iris Bucherv Landrat des Kreises Düren [2007] ECR I-9161, paras 34ff, 46; and Case C-258/04 Office national de l'emploi $v$ Ioannis Ioannidis [2005] ECR I-8275, para $31 \mathrm{ff}$. While not explicitly repeating D'Hoop, the reasoning matches its principles in addition in Case C-499/06 Halina Nerkowska v Zakład Ubezpieczeń Społecznych Oddział w Koszalinie [2008] ECR I-3993, para 40ff and Case C-192/05 K Tas-Hagen and RA Tas $v$ Raadskamer WUBO van de Pensioen en Uitkeringsraad [2006] ECR I-10451, paras 37-39.

68 Terms used in Stewart (n 64) para 95.

69 Although the Court classically is not sympathetic to such administrative burdens: Case 104/75 Adriaan de Peijper, Managing Director of Centrafarm BV [1976] ECR 613, para 18.

70 In a more general sense, legal certainty is an important precondition for effective 'rights' (and their limits) and the freedom to act, see D Chalmers, 'The Dynamics of Judicial Authority and the Constitutional Treaty' (2004) Jean Monnet Working Paper 5/04, 20.
} 
to go through the lengthy process of amendment as the case law of the ECJ develops, but at the same time lays the main onus to determine what EU law requires in this context with the agency responsible for the implementation of the law. It will then depend on the make-up of the agency and the competence of its staff whether it is capable of determining the correct application of EU law in this regard. Moreover, and perhaps more cynically, compliance with EU law or a progressive interpretation thereof, especially where this leads to great eligibility for foreign students and thus more costs, may not be foremost on the agenda of an administrative agency faced with increasing pressure, in the light of the economic crisis, to balance budgets. Finally, in casu the website of the study grant authority only sets out very broad and simple guidelines as to when it will grant study grants under EU law. ${ }^{71}$ This makes it difficult for an external examiner to determine whether administrative practice is in accordance with EU law, as well as for students to know their rights and when they can invoke them without consulting an expert. In the light of such practices, one can imagine that uncertainty would be increased even more if the Court were to insist on individual assessments only.

A final point against solely relying on individual assessments is the degree of arbitrariness and denial of (formal) justice that may result from treating each case separately and without reference to (generalisable) principles. ${ }^{72}$ As such, it is submitted here that a combination of the two approaches is perhaps best: ${ }^{73}$ a set of general, widely disseminated and alternative indicative criteria (eg specific periods of residence, having obtained a secondary education diploma in the host State ${ }^{74}$ ) used as a basis for initial assessment and, upon application, an individual assessment considering amongst other elements family relations (eg being married to a host Member State national, ${ }^{75}$ or being dependent on individuals having a connection with the host State $\left.^{76}\right)$, past periods of

\footnotetext{
71 See Österreichische Studienbeihilfenbehörde <http://www.stipendium.at/studienfoerderung/studienbeihilfe/wer-hat-anspruch/> accessed 2 November 2013.

72 C O'Brien, 'Real Links, Abstract Rights and False Alarms: The Relationship Between the ECJ's “Real Link” Case Law and National Solidarity' (2008) 33(5) European Law Review 643, 661. She also points out that Court-made 'policy' is litigant-led, with the results that legal developments in social welfare may be prompted by individuals that are already articulate, affluent and can afford sound legal advice rather than by the less fortunate whom social welfare is in the end designed to protect.

73 Recently also endorsed by AG Sharpston in her Opinion in Joined Cases C-523/11 and C-585/ 11 Laurence Prinz $v$ Region Hannover and Philipp Seeberger v Studentenwerk Heidelberg, delivered 21 February 2013, para 106.

74 Considered relevant in Morgan and Bucher (n 67) para 45.

75 Prete (n 67) para 48.

76 Stewart (n 64) para 100.
} 
employment ${ }^{77}$ or residence, ${ }^{78}$ and/or perhaps (provision of proof of) being able to speak the language of the host State. ${ }^{79}$ Overall, therefore, there are good reasons to question the validity of the strict application of the Förster criterion. In fact, it is submitted here that if Förster came before the Court now, it might or should rule differently. Consider that Jacqueline Förster had lived in the Netherlands for three years, was in a relationship with a Netherlands resident and had worked at a call centre and pursued full-time practical training at a Dutch school providing secondary special education for pupils with behavioural problems (which moreover suggests that she probably spoke near-fluent Dutch). She thus seems to be a perfect illustration of someone who has established a link with the host State which is not sufficiently reflected in the simple assessment of the duration of residence in the host State.

A more integrative, wide-ranging approach is thus much to be preferred. Moreover, such an approach would give real effect and meaning to Union Citizenship as the fundamental status of nationals of the Member States of the EU, and would do greater justice to the right of equal treatment that is intrinsic to that status. ${ }^{80}$

Concerning travel concessions for students the situation is somewhat different. In Commission $v$ Austria (student travel concessions), ${ }^{81}$ the Court for the first time specified that Member States are not free in choosing genuine link indicators: rather, regard must be had to the constitutive elements, and in particular the nature and purpose, of the benefit claimed. ${ }^{82}$ In casu, the legislation of several Länder tied the receipt of (state-financed) student travel concessions to the condition that the parents of the student should be in receipt of Austrian child support. However, perhaps rightly expecting that the Court would not accept this construction, ${ }^{83}$ Austria relied in the alternative on Article 24(2) of Directive 2004/38 to specify a strict genuine link criterion: student travel concessions need only be provided to those individuals having obtained a right of permanent residence. The Court was having none of it, however:

\footnotetext{
77 As seen in Commission $v$ the Netherlands ( $\mathrm{66}$ ) paras 65-66, participation in the labour market establishes a (sufficient) link of integration with the host State. Moreover, past employment was also considered relevant in Nerkowska (n 67) paras 42-43, and in Stewart (n 64) para 100. Note that past employment relevant for assessing a genuine link with the host State should be distinguished from the position of 'ex-worker' and the rights attached to that status in some cases (including, eg, under some conditions equal treatment as regards study grants).

78 Nerkowska (n 67) paras 42-43; and Stewart (n 64) para 101.

79 Joined Cases C-523/11 and C-585/11 Laurence Prinz v Region Hannover and Philipp Seeberger $v$ Studentenwerk Heidelberg [2013] (nyr) para 38.

80 See the formulation in Grzelczyk (n 7) para 31.

81 Commission $v$ Austria (student travel concessions) (n 55).

82 ibid para 63.

83 ibid paras 44-50.
} 
whereas it held that student travel concessions could be seen as maintenance aid, the derogation of Article 24(2) only applied to study grants and loans, a concept which should be interpreted narrowly. ${ }^{84}$ Rather, having regard to the nature and purpose of the benefit claimed, (proof of) enrolment in higher education was a sufficient indicator to establish the requisite genuine link between the student and the host State for the purposes of claiming the travel concession. ${ }^{85}$ This judgment has potentially far reaching consequences for a number of Member States which have schemes in place to provide students with public transport discounts. These types of concessions may no longer 'hide' behind the general study grant/loan concept and the (albeit contestable) five-year Förster residence criterion. Consider, for example, that the Netherlands offers a travel scheme ${ }^{86}$ for students which is tied to receipt of 'study finance' under the Wet Studiefinanciering (a mixed study grant/loan system). ${ }^{87}$ In the light of the Commission $v$ Austria judgment, this connection must be dropped and all EU national students who have enrolled in a Dutch university must be held to be entitled to this travel scheme under the same conditions as Dutch nationals.

2.2.3 Who can access study grants in the host Member State II: the 'EU citizen +', economically active EU nationals and their family members

With Commission $v$ the Netherlands (export of study grants), the Court integrated its long-standing case law as regards the equal treatment rights of economically active EU nationals into its more recent jurisprudence concerning EU citizenship. It held, in essence, that economically active EU nationals are 'EU citizens +': they have a right to equal treatment with the host Member State nationals (as does any EU citizen) as regards social advantages offered by the host Member State, but unlike 'regular' EU citizens they must be presumed to have established a genuine link with the host Member State as a result of their contribution to the host economy. ${ }^{88}$ Notwithstanding this clear general principle, the case law of the Court is quite complex as to who is entitled when. Three positions can be distinguished: ${ }^{89}$

\footnotetext{
84 ibid paras 53-56.

85 ibid para 63.

86 See Article 3.7 Wet Studiefinanciering 2000: it provides students with free travel during either the week or at the weekend and a discount for travel on other days.

87 Articles 3.1 - 3.3 Wet Studiefinanciering 2000.

88 Commission $v$ the Netherlands (n 66) paras 63-66.

89 Note the categories discussed below concern primarily workers and their family members. However, following Case C-337/97 CPM Meeusen v Hoofddirectie van de Informatie Beheer Groep [1999] ECR I-3289, paras 26-29, the same applies, mutatis mutandis, to selfemployed individuals and their family members.
} 
1. The student-worker: the student (enrolled in full-time post-secondary education) with an EU nationality who qualifies as a Union worker. Case law suggests that ten hours of remunerated work per week in a subordinate relationship of employment is sufficient in this regard. ${ }^{90}$ The fact that a student-worker came to the host Member State with the principal intention of studying does not disqualify him from obtaining this worker-status. ${ }^{91}$ This allows the student-worker to rely on the principle of non-discrimination found in Article 45(2) TFEU, which is further elaborated in Regulation 492/2011. Lair and Brown, as well as the recent case $L N$, confirm that study grants (and scholarships ${ }^{92}$ ) constitute a social advantage within the meaning of Article $7(2)$ of what is now Regulation 492/201 $1^{93}$ and that, as such, student-workers have a right to claim such grants under the same conditions as host Member State nationals. Additional conditions are prohibited: the Member State cannot make the provision of the grant conditional on the student-worker having completed a minimum period of employment prior to the application, ${ }^{94}$ nor can it impose a residence requirement ${ }^{95}$ (allowing frontier workers to claim equal treatment in their state of employment). Finally, the ex-workerturned-student can continue to rely on his previous worker status to claim study allowances where there is continuity between the previous employment and the studies subsequently commenced. In the case of involuntary unemployment, such continuity is not required where the labour market conditions are such as to oblige the ex-worker to train in a different field. A further condition for ex-worker status is that the (previous) work must not have been merely ancillary to the subsequent studies. ${ }^{96}$

\footnotetext{
90 See classically Case 139/85 RH Kempf $v$ Staatssecretaris van Justitie [1986] ECR 1741 (12 hours) and recently Case C-14/09 Hava Genc $v$ Land Berlin [2010] ECR I-931, paras 9, 25-27 (5.5 hours per week may be sufficient). See further: Opinion of AG Geelhoed on Case C-413/01 Franca Ninni-Orasche $v$ Bundesminister für Wissenschaft, Verkehr und Kunst [2003] ECR I-13187, para 33; and Case C-444/93 Ursula Megner and Hildegard Scheffel $v$ Innungskrankenkasse Vorderpfalz, now Innungskrankenkasse Rheinhessen-Pfalz [1995] ECR I-4741, paras 18-20.

91 Case C-46/12 LNv Styrelsen for Videregående Uddannelser og Uddannelsesstøtte [2013] (nyr) paras 46-47.

92 Case 235/87 Annunziata Matteucci $v$ Communauté française of Belgium and Commissariat général aux relations internationales of the Communauté française of Belgium [1988] ECR I-5589, paras 11-12. Moreover, the basis on which the scholarship was made available (in casu, a bilateral treaty) was irrelevant for the application of the principle of equal treatment.

93 Lair (n 6) paras 22-24; Brown (n 34); and LN (n 91) para 50.

94 Lair (n 6) paras 40-42.

95 Meeusen (n 89) paras 18-25.

96 Brown (n 34) paras 25-27.
} 
2. The student, a child ${ }^{97}$ of a Union worker, has two sources of rights: Article 10 and Article 7(2) of Regulation 492/2011. The former is activated once three conditions are fulfilled. ${ }^{98}$ First, the child must reside in the Member State in which one of his or her parents is or has been employed as a Union worker. Secondly, the child must have become installed in the host Member State during the exercise of the right of free movement of workers by either of his or her parents. Thirdly, the child must enrol in a form of education. Once these factors coincide at some point in time, ${ }^{99}$ the awesome protection that is Article 10 of Regulation 492/2011 becomes activated. It provides the child with a self-standing right of residence ${ }^{100}$ and full equal treatment as regards benefits facilitating educational attendance ${ }^{101}$ (including study grants ${ }^{102}$ ) for the purposes of continuing his or her education. It is not necessary for the Union worker-parent, from whom the right was initially derived, to retain his or her status as worker for these rights to remain active; nor is it necessary for this parent to even remain in the host Member State. ${ }^{103}$ The age of the child or his or her dependence on the worker-parent is irrelevant for the purposes of relying on Article 10. ${ }^{104}$ The only limitation of Article 10 of Regulation 492/2011 is the fact that it requires the residence of the child in the host Member State. It does not, therefore, cover the situation of frontier families, whereby the family resides in Member State A, but the workerparent is employed in Member State B. This is where Article 7(2) of Regulation 492/2011 comes in: in Bernini, the Court ruled that the award of study grants to children of workers constitutes a social advantage for the worker under that article (even where study

\footnotetext{
97 Here, one must be careful not to make reference to the concept of 'child' adhered to in Article 2(2)(c) of Directive 2004/38. Rather, the starting point is simply the individual as descendant of the worker or his spouse, regardless of his or her nationality.

98 See Case C-480/08 Maria Teixeira $v$ London Borough of Lambeth, Secretary of State for the Home Department [2010] ECR I-1107, paras 44-54, 72-74; and Case C-310/08 London Borough of Harrow v Nimco Hassan Ibrahim, Secretary of State for the Home Department [2010] ECR I-1065, paras 33-43.

99 It is not necessary for the worker-parent to have retained worker status and/or to have been employed at the point where the child started his or her education.

100 Case C-413/99 Baumbast and $R v$ Secretary of State for the Home Department [2002] ECR I-7091, paras 50-54.

101 Case C-7/94 Landesamt für Ausbildungsförderung Nordrhein-Westfalen v Lubor Gaal [1995] ECR I-1031, para 19.

102 Casagrande (n 3) paras 5-8; and Joined Cases 389-390/87 GBC Echternach and A Moritz $v$ Minister van Onderwijs en Wetenschappen [1989] ECR 723, paras 33-35.

103 Baumbast (n 100) paras 50-52, 54, 68-74. See also: Echternach and Moritz (n 102) paras 19-21; Teixeira (n 98) paras 49-50, 53; and Ibrahim (n 98) paras 38-39, 42.

104 Gaal (n 101) paras 23-30.
} 
grants are directly granted to the student). ${ }^{105}$ Meeusen confirmed that the position of frontier workers in particular was also covered; the child residing in Member State A can rely on the worker status of his or her parent in Member State B to claim equal treatment as regards study grants in the latter Member State. ${ }^{106}$ At the same time, the right is somewhat more limited than Article 10: for the right to remain active, the worker-parent must continue to support the student and, as Fahmi suggests, the worker-parent must continue to have the status of worker in the host State. ${ }^{107}$ Further conditions may moreover be imposed, to be discussed below, where the student seeks not to study in the Member State of employment of the worker-parent, but rather to export the study grants for a course abroad.

3. The family member ${ }^{108}$ of the Union worker (eg, in particular, the spouse or registered partner). For the most part, the relevant source of rights providing equal treatment as regards study grants for the 'rest category' of family members is Article 7(2) of Regulation 492/2011. While the ECJ, to the knowledge of this author, has never explicitly confirmed that Article 7(2) of Regulation $492 / 2011$ can be relied upon by family members (non-children) to claim equal treatment as regards study grants, it is nevertheless likely that such family members could rely on that Article in the light of the broad-ranging case law of the Court interpreting the provision. ${ }^{109}$ Whereas Article 24 of Directive 2004/38 is also an option, that right seems to be limited to Union citizens (and their family members) 'residing on the basis of this Directive in the territory of the host Member', thereby excluding frontier workers. Moreover, the Article is particularly without value to children of Union workers who can instead derive more extensive rights from other sources.

\footnotetext{
105 Case C-3/90 MJE Bernini $v$ Minister van Onderwijs en Wetenschappen [1992] ECR I-1071, paras 24-25.

106 Meeusen (n 89) paras 19-24.

${ }^{107}$ Family members of ex-workers can in some circumstances rely on the right of equal treatment as regards social advantages where these are intrinsically linked with the exworker's prior worker status. Maintenance grants for study purposes do not seem to be among that category of social advantages: see Case C-33/99 Hassan Fahmi and M Esmoris Cerdeiro-Pinedo Amado $v$ Bestuur van de Sociale Verzekeringsbank [2001] ECR 2415, paras 33-47.

108 Reference for the concept of family member can here be made to Article 2 of Directive 2004/38 which replaces the relevant sections of what used to be Regulation 1612/68 in this regard.

109 Implicitly, this can be said to follow from Forcheri (n 30) paras 10-18. In a more general sense, one can refer to Case 32/75 Anita Cristini $v$ Société nationale des chemins de fer français [1975] ECR 1085.
} 


\subsubsection{Export of study grants}

The case law of the Court as regards the export of study grants is still very much an evolving jurisprudence. As a basic point of departure, one may distinguish two types of situations in export cases:

- The EU citizen who seeks to export study grants provided by his own Member State in order to study abroad.

- The migrant EU citizen, a national of Member State A, who has a right to equal treatment with the nationals of host Member State $\mathrm{B}$ and seeks to export those grants to Member State C.

It should further be mentioned that EU law currently does not confer a right to export such study grants; it is only where the possibility is offered by a Member State that the conditions attached to such export are scrutinised for compatibility of EU law. ${ }^{110}$ Many Member States do in fact, in line with the Bologna objectives as well as EU initiatives, ${ }^{111}$ provide for portable study grants, but at the same time have devised various conditions seeking to limit the number of eligible persons, targeting both their own nationals as well as foreign Member State nationals perceived to have only a limited connection with the particular Member State. In the past, the Court already had occasion to reject as incompatible with EU law the requirement that study grants cannot be exported to the state of nationality; ${ }^{112}$ moreover, a so-called 'first stage criterion' under which the portability of study grants under the German scheme was made conditional on the individual in question having completed a year of study in a German institution, and subsequently enrolling in a course of study that followed up on that initial study period was considered an unjustified restriction of free movement rights under Article 21 TFEU. ${ }^{113}$

Recently popular, however, have been the imposition of (durational) residence requirements usually of the variety whereby an individual must have lived x out of y years in Member State A before being allowed to export those same grants for a course of study offered in an educational establishment in Member State B. Such requirements affect in particular two groups. On the one hand, the residence aspect excludes Union frontier workers and their family members from the possibility to export study grants offered under the legislation of the Member State

110 Morgan and Bucher (n 67) paras 22-28. This was recently confirmed explicitly in Case C-220/12 Andreas Ingemar Thiele Meneses v Region Hannover [2013] (nyr) para 25; and Case C-275/12 Samantha Elrick v Bezirksregierung Köln [2013] (nyr) para 25.

111 See A Schrauwen, 'Access to and Portability of Student Grants and Loans. Where Targets Meet Free Movement Law' (2011) Amsterdam Law School Legal Studies Research Paper No 2011-38, 3-7.

112 Case C-308/89 Carmina di Leo v Land Berlin [1990] ECR I-4185, para 16.

113 Morgan and Bucher (n 67) paras 22-51. 
of employment. The durational aspect, moreover, also excludes Union workers and their family members who have only briefly resided in the State of employment. On the other hand, the residence requirement also affects the nationals of the Member State who lived some time outside its territory. ${ }^{114}$ Note for migrant EU nationals who are not economically active, such residence requirements have little significance. This group is in principle, with the caveats noted above, required to reside in the host Member State for a period of five years before being eligible for study grants there, therewith normally satisfying the requirements for the export of study grants as well.

\subsubsection{EU citizens and their Member State of nationality}

The leading case in this regard is the recent Prinz and Seeberger case. ${ }^{115}$ The applicants were two German nationals who fell afoul of the requirement imposed by the Bundesausbildungsförderungsgesetz for the financing of studies abroad for the duration of more than one year: in such circumstances, the applicants had to have had their permanent residence $^{116}$ in Germany for three years prior to the application. Both Prinz and Seeberger had spent some time in Germany over the course of their lives, and had received some primary (Seeberger) and secondary education (Prinz and Seeberger) there. They had also resided over 2.5 years in Germany directly prior to their application, in both cases therefore falling just short of the three-year requirement.

The Court relied on its classic formula to find a restriction of the free movement rights of the applicants: the durational residence requirement was liable to put those Member State nationals having exercised their free movement rights at a disadvantage. ${ }^{117}$ In its defence, Germany submitted that the residence requirement was necessary to circumscribe the circle of beneficiaries of a study grant to those demonstrating a minimum degree of integration with Germany with a view to avoid an unreasonable financial burden: a genuine link requirement meant to define the boundaries of solidarity. The Court, however, rejected the rule in principle as being 'too general and exclusive' as it did not take into account other factors which connected the students to German society, finding alternative links in that:

\footnotetext{
${ }^{114}$ Note for migrant EU nationals who are not economically active, such residence requirements have little significance. This group is in principle, with the caveats noted above, required to reside in the host Member State for a period of five years before being eligible for study grants there, therewith normally satisfying the requirements for export of study grants as well.

115 Prinz and Seeberger (n 79). Recently confirmed in substance in Thiele Meneses (n 110).

116 Permanent residence for the purposes of the law was defined as the place where the person's centre of family interest lies. See Prinz and Seeberger (n 79) para 3.

117 ibid para 27.
} 
(...) the student is a national of the State concerned and was educated there for a significant period or on account of other factors such as, in particular, his family, employment, language skills or the existence of other social and economic factors. ${ }^{118}$

Overall, as already remarked above, the Court here clearly reiterates its recent emphasis on a holistic approach to the assessment of whether an individual has a 'genuine link' with the host Member State: a single requirement, in casu one of durational residence, used as an indicator measuring integration, is insufficient to capture the whole of the relationship between the individual and a Member State. This will have farranging consequences, as a number of Member States rely on the blanket use of durational residence requirements to determine eligibility for their exportable study grants. ${ }^{119}$ This case also reinforces the above conclusion that the Förster five-year criterion is probably no longer good law.

\subsubsection{2 'EU citizens +' and durational residence requirements of the host State}

After Commission $v$ the Netherlands (export of study grants), it is clear that durational residence requirements are unlawful where they are applied to Union workers and their family members who reside in the host Member State. In casu, the Court ruled that a requirement to have resided in the Netherlands for three years in the six years preceding the application for the export of study grants amounted to indirect discrimination, which, moreover, could not be justified. The first submission by the Netherlands had argued that it was legitimate for a Member State to require the recipients of such study grants to have a genuine link with that State; as seen above, the Court rejected this on the grounds that Union workers and their family members by reason of their economic contribution to the host State had to be presumed to have such a link. ${ }^{120}$ The second ground held that the residence requirement was a means to achieve certain mobility aims. It had the dual aim of identifying those individuals who had been statically residing in one place (symbolised by the requirement of immobility for three years in the last six) with a view to providing specifically those individuals with a mobility grant, while simultaneously seeking to ensure that those having received this mobility grant would

\footnotetext{
118 ibid para 38. See also Thiele Meneses (n 110), paras 40-41 where the Court did not exclude the possibility that the applicant in question, who had only attended German schools abroad (eg established in Istanbul), could nevertheless be considered sufficiently connected to Germany.

119 See for an overview of Member States who apply such measures the table in A Hoogenboom, 'Export of Study Grants and the Lawfulness of Durational Residency Requirements: Comments on Case C-542/09, Commission v the Netherlands' (2012) 14 European Journal of Migration and Law 417, 429.

120 Commission $v$ the Netherlands (n 66) paras 60-67.
} 
after their study period abroad return to the Netherlands (symbolised by the condition requiring durational residency in the Netherlands). The Court held, somewhat surprisingly in the absence of any evidence offered by the Netherlands for the above-mentioned claims, that the residence requirement was appropriate to secure both aims. ${ }^{121}$ However, it rejected the necessity of the measure: requiring the fulfilment of specific periods of residence risked attaching too much importance to an element not necessarily representative of the actual degree of attachment. ${ }^{122}$

With frontier workers and their family members, the picture is more mixed. In Giersch, ${ }^{123}$ a set of students who were family members of frontier workers sought to export their study grants and challenged the lawfulness of a residence criterion imposed by Luxembourg (on EU nationals and Luxembourg nationals alike) as a condition to receive study grants (whether for studies in Luxembourg or abroad) on the basis of Article 7(2) Regulation 492/2011. ${ }^{124}$ The Court found the residence criterion to constitute indirect discrimination, but was receptive to the ground for justification put forward by Luxembourg: the latter sought to increase the proportion of the population with a higher education degree with a view to transition to a knowledge economy. ${ }^{125}$ The mechanism relied upon was similar to the argument by the Netherlands in Commission $v$ the Netherlands (export of study grants): residence prior to the studies abroad was argued to be a good predictor of future place of residence after the studies abroad. The Court's approach was surprising.

First, it ended the unquestioning harmonisation of the legal position of workers resident in the host State and frontier workers: 'the frontier worker is not always integrated in the Member State of employment in the same way as a worker who is resident in that State'. ${ }^{126}$ Secondly, the Court went on to find that indeed the residence requirement was appropriate to achieve the aim desired by Luxembourg: students resident in Luxembourg prior to the study abroad were, in its view, inherently more likely to return there afterwards and integrate into the labour market. ${ }^{127}$ On necessity grounds, the rule was rejected, however, with the Court

\footnotetext{
${ }^{121}$ In other words, that past residence was a relatively good predictor of subsequent place of study as well as the propensity to return to the Member State of past residence: Commission $v$ the Netherlands (n 66) paras 76-79. AG Sharpston, in contrast, had argued that there was no logical link between past residence and propensity to return after studies abroad. See Opinion of AG Sharpston in Case C-542/09 Commission v the Netherlands, delivered on 16 February 2012, para 147.

122 Commission $v$ the Netherlands (n 66) para 86.

${ }^{123}$ Case C-20/12 Elodie Giersch, Benjamin Marco Stemper, Julien Taminiaux, Xavier Renaud Hodin, Joëlle Hodin v Luxembourg [2013] (nyr).

${ }^{124}$ See Opinion of AG Mengozzi in Case C-20/12 Giersch, delivered on 7 February 2013, para 1.

125 Giersch (n 123) paras 48, 53.

126 ibid para 65.

127 ibid para 67.
} 
adopting similar reasoning to that above: the use of a sole criterion as determinative of the degree of attachment of an individual to the host Member State risked disregarding other links with the host State. In particular, the Court criticised the criterion for excluding the situation where the student resides abroad but studies in Luxembourg, where the parents of the child live in Luxembourg and support the child residing abroad and, finally, for excluding the children of migrant workers who have worked in Luxembourg for a significant period of time. ${ }^{128}$ With regard to the latter, the 'pure frontier family' (all family members live abroad), the Court held that Luxembourg could make the grant of maintenance aid for study purposes conditional on the completion of a minimum duration of employment of the frontier-worker parent before the study grants had to be granted to the child and seemed to suggest, with reference to Article 24(2) juncto 16 Directive 2004/38, that a five year period would be appropriate in the context of study grants. ${ }^{129}$ Finally, and technically obiter dictum, the Court also helpfully pointed to some other tools at the disposal of Luxembourg in this regard. It could, for instance, introduce anti-cumulation provisions whereby the aid provided by Luxembourg would be reduced by the amount received in another Member State. Or, somewhat shockingly, the Court suggested that Luxembourg, in essence, could introduce a financial incentive or penalty (depending on one's position) to enforce the return of the study grant recipient to Luxembourg to take up employment there (eg a system whereby an initial study loan would only be converted to a grant upon such return). ${ }^{130}$

Combining Commission $v$ the Netherlands (export of study grants) and Giersch, we see a number of interesting points. As seen, frontier workers are no longer unquestionably to be harmonised with resident Union workers; a ruling by which the Court in essence partly overturned its Meeusen rule. ${ }^{131}$ In fact, the Court seems to have constructed a certain hierarchy. At the top stands the fully migrated Union worker and his or her family members. Here exists (at the very least) a dual link with the host Member State: residence and the contribution to the host economy/ public purse as a result of the employment. Here a Member State is required to provide for equal treatment with the host Member State nationals as regards social advantages without further questioning.

On the bottom rung stands the pure frontier worker and his or her family members. Here the connection of the 'host' Member State is reduced to a single link: that of the employment of the Union worker. Giersch confirms that in such circumstances Member States can require, per-

\footnotetext{
128 ibid para 75.

129 ibid paras 78-80.

${ }^{130}$ See ibid para 79.

131 Meeusen (n 89) paras 19-24.
} 
haps for all social advantages to be enjoyed in the state of employment, a degree of 'strength' of that single link. This may be assessed by determining, for example, whether the individual is engaged in more than minor employment ${ }^{132}$ or has been employed in the host State for a number of years (as seen above).

The middle ground is occupied by the Union worker and his or her family that have a diffuse set of links with the host State. The basis is again formed by employment in the host State, but a number of other links must also be considered, such as whether part of the family lives in the host State or studies there. ${ }^{133}$ Where such a multitude of links exist, it is likely that the 'strength' of the employment link becomes less determinative for the right to equal treatment as regards social advantages in the State of employment to arise. Here, the Member State has less freedom to impose conditions of prior employment and the like: in essence its discretion is, or should be, limited to merely establishing the existence of links beyond mere employment. ${ }^{134}$

Three criticisms can, however, be levelled against the judgment of the Court in Giersch. First, the Court accepted the proposed 'social objective' of Luxembourg too easily. In the light of the overall EU objective of increasing the number of tertiary diploma holders, it held that: 'an action undertaken by a Member State in order to ensure that its resident population is highly educated and to promote the development of the economy pursues a legitimate objective which can justify indirect discrimination on grounds of nationality'. ${ }^{135}$ This does sound like a reasonable objective, but in the context of the case it is questionable: what action did Luxembourg undertake in this regard? One can perhaps assume that the Court meant to refer to the introduction of the possibility to export study grants in order to attend higher education abroad in a general sense (in view, also, of the lack of higher education opportunities in Luxembourg itse1f). Fine, but this does not explain or justify the residence requirement circumscribing the beneficiaries of exportable study grants: it seems to this author very difficult to make an argument that this requirement, specifically, contributes to the aim of increasing the number of residents in possession of a tertiary degree. Why would the introduction or the existence of such a requirement, as a prerequisite for study grants, induce a greater number of individuals to settle in Luxembourg after their studies than the absence of such a requirement?

\footnotetext{
${ }^{132}$ See Case C-212/05 Gertraud Hartmann v Freistaat Bayern [2007] ECR I-6303, para 34ff; and Case C-213/05 Wendy Geven v Land Nordrhein-Westfalen [2007] ECR I-6347, para $25 \mathrm{ff}$.

133 Giersch (n 123) para. 75.

134 ibid para 75 .

135 ibid para 56.
} 
Rather, the residence requirement, as was submitted in Commission $v$ the Netherlands, is either meant to limit the circle of beneficiaries to those who are sufficiently integrated with a view 'to avoid an unreasonable financial burden which could have consequences for the very existence of the assistance scheme'136 and/or to safeguard the 'investment' made in mobile students (whereby resident students are deemed as somehow inherently likely to return to contribute to economic and social life in Luxembourg). ${ }^{137}$ It is the latter point that the Court focuses on in Giersch, which is however not related to the social objective that Luxembourg claimed. Considering the potentially important implications of this case for both the legal position of frontier workers, as well as for recipients of study grants (see the discussion as regards the return obligation below) this flawed reasoning of the Court is regrettable and confuses the context in which the legal principles are developed.

A second point relates to the hierarchical scheme created by the Court in Giersch ranging from resident Union workers and their family members to the pure frontier family. In the past, the Court quite consistently insisted on the harmonisation of the position of the latter with that of the former when it came to claiming benefits in the Member State of employment. This also makes sense in the light of the underlying logic of the Court referred to above: a migrant EU worker who has helped finance the social benefits he claims is in principle entitled ('sufficiently integrated') to receive them.

The danger of this approach is that the frontier worker may become a distinctly unattractive position. As O'Brien puts it, frontier work in the $\mathrm{EU}$ is both 'the apotheosis of free movement and the anomalous exception to the principle of social integration'. ${ }^{138}$ Giersch further compounds this tension: because of the Court-sanctioned possibility of Member States to impose durational work requirements, a Union frontier worker may end up in a situation, at least initially, whereby neither the Member State of residence (because the Union frontier worker and his migrant family are not (yet) sufficiently integrated) nor the Member State of employment (for the first $\mathrm{x}$ amount of working years) is obliged to provide certain soci-

\footnotetext{
136 Commission $v$ the Netherlands (n 66) para 56.

137 See also the argument submitted by Luxembourg as summarised in the Opinion of AG Mengozzi in Case C-20/12 Giersch, delivered 7 February 2013, para 38 and in the order for reference, para 29 available at <http://www.minbuza.nl/binaries/content/assets/ecer/ ecer/import/hof_van_justitie/nieuwe_hofzaken_inclusief_verwijzingsuitspraak/2012/c020-12-verwijzingsbs.pdf> accessed 2 November 2013.

${ }^{138}$ C O’Brien, 'Case C-212/05, Gertraud Hartmann v. Freistaat Bayern, Judgment of the Grand Chamber of 18 July 2007 nyr; Case 213/05, Wendy Geven v. Land Nordrhein-Westfalen, Judgment of the Grand Chamber of 18 July 2007 nyr; Case 287/05, D.P.W. Hendrix v. Raad van Bestuur van het Uitvoeringsinstituut Werknemersverzekeringen, Judgment of the Grand Chamber of 11 September 2007' (2008) 45 CML Rev 499, 499-501.
} 
al advantages (such as study grants). ${ }^{139}$ Thus, in the absence of a default responsible Member State, a large group of EU citizens (some 780,000 ${ }^{140}$ ) may fall between two stools where it concerns benefits provided on the basis of solidarity, such as study grants. It would thus perhaps be better for the Court to return to its previous line of case law. The concerns of 'abuse' (such as study grant forum shopping) raised by the Member States should not be overstated: it is highly unlikely that the worker-parent would change his or her place of employment to another Member State solely in order to claim social assistance there, such as study grants, for his or her dependent child.

Finally, a point should be made as regards the fact that the Court in Giersch seemed to suggest that a 'return obligation', complete with measures for its enforcement, for students provided with exportable study grants would be allowed. Here we see the Court endorsing a direct form of reciprocity: maintenance aid for study purposes is only provided (or only provided under favourable conditions) as a quid pro quo for the expected contribution of the person so subsidised to the economy of the subsidising Member State. This return obligation, and its underlying logic, should be rejected in the strongest possible terms.

In a basic sense, the return obligation violates the central tenets of an internal market characterised by free factor movement. After all, following Giersch, Member States may require the availability to the national labour market of the student who was invested in (by penalising those who do not return). This is surely a direct contradiction of the free movement of workers (and/or freedom of establishment), the essence of which is that a Member State national should be able to move to any Member State where the demand for his or her skills is highest. ${ }^{141}$ This in fact amounts to the repartitioning of the European labour market into national labour markets. There is also a strong moral aspect: if financial support is provided for a student, does this then entitle society, as a right, to benefit from this person's labour and/or presence? This buying of a 'stake' in a person's life and productive capacity seems, to put it mildly, highly questionable. ${ }^{142}$ Moreover, it has problematic social justice implications as the obligation is regressive in nature: it is most likely to affect those most needing financial support, lower to middle class students. This damaging effect is reinforced if students are in essence forced

\footnotetext{
139 See this problem also in the Opinion of AG Pergola in Case C-337/97 Meeusen [1999] ECR I-3289, paras 15-20 and the facts underlying that case.

140 G Nerb et al, 'Scientific Report on the Mobility of Cross-Border Workers within the EU27/EEA/EFTA Countries' (Final Report 2009) VII (2009), 16-27 <http://ec.europa.eu/social/BlobServlet?docId=3459\&langId=en $>$ accessed 2 November 2013.

${ }^{141}$ P Craig and G de Búrca, EU Law: Text, Cases and Materials (OUP 2011) 582.

${ }^{142}$ For an extensive discussion, see S Dumitru, 'Skilled Migration: Who Should Pay for What? A Critique of the Bhagwati Tax' (2012) 14(1) Diversities 9, 13-16.
} 
to look across borders because the domestic higher education system does not offer the desired course of study (as is assuredly the case in Luxembourg) $\cdot{ }^{143}$ Finally, more practically, one may wonder how long the student in question is required to be 'available to the national labour market'. Would this be linked to the number of years that he or she received financing, or the amount? Either way, this may generate a strong lock-in effect for the student as regards an initial study choice (where he or she would prefer a different one) for fear of generating a greater work obligation towards the home State in this regard, quite separate from or in addition to any repayment obligation of study loans that may exist in any case. In addition, what happens if the national labour market is saturated or the particular skills of the student are not in demand? Is the student then forced to choose between unemployment and a financial penalty?

Overall, it would seem that a return obligation is an ill-advised mechanism, raising a host of legal, moral and practical issues. A Member State would do better to pursue labour market policies designed to attract foreign talent (the carrot) rather than trying to shepherd its stray students back to their home coral by means of a stick.

\subsection{Conclusion: the case law of the Court on student mobility and its consequences}

The above discussion has revealed that the case law of the Court of Justice on student mobility has grown extensively over the last 40 years or so. It would seem fair to conclude that the legal principles developed have strongly contributed to an increased mobility of students in the EU by providing mobile learners with extensive rights both as regards access to education offered abroad as well as vis-à-vis study facilitating benefits offered by the host or home State. However, the discussion (at least implicitly) has also revealed increasing concern, particularly noticeable in recent cases, on the part of the Member States as regards the (alleged) negative financial and economic consequences of student mobility. These worries include the increased pressure on the public purse as regards the financing of higher education institutes generated by the influx of foreign EU students (at issue, inter alia, in Bressol). As will be seen below, such concern is not fully baseless: the 'Member State subsidy', the difference between the tuition fee paid by the student and the actual cost of educating the student, is in many EU countries extensive and must, as seen, also be extended to migrant EU nationals. In addition, renewed attempts by the Member States to limit eligibility for study grants of student-workers (such as in the case of $L N$ referred to above), as well as the export

$\overline{{ }^{143} \text { See also Case C-20/12 Giersch [2013] (nyr) para } 60 .}$ 
cases in which Member States package their attempts to justify their imposed restrictions in terms of a fear of a collapse of the study assistance scheme or with a view to safeguard a return on the portable study grants provided, show that economic concerns play an ever large role in policymaking in this regard. Coupled with a context of a still on-going 'sovereign debt crisis' in which Member States are under increasing pressure to get their public accounts in order, it is not surprising that the longer running discussion regarding the (allocation of the) financial responsibilities of Member States for the free moving student in the European Union has acquired new urgency. However, the debate in this regard is often characterised by myriad unsubstantiated claims: it is easy to argue that educating the foreign student must cost the host State 'something', and that this constitutes a burden that cannot be extended indefinitely, ${ }^{144}$ but what about the (potential) benefits? It is to this issue that we now turn, in an attempt to clarify the sometimes rather murky discussion.

\section{Student mobility in times of economic crisis: luxury product or necessity?}

Public spending on tertiary education in the EU 27 averages about $1.1 \%$ of $\mathrm{GDP}^{145}$ (some $€ 140$ billion $^{146}$ ) and services some 20 million students (a number which is rising). ${ }^{147}$ Moreover, the unit cost of a student in tertiary education (estimated at $€ 9,400$ per annum) is the highest of all educational levels ${ }^{148}$ and is borne almost entirely by the public purse: private spending on education remains marginal as a source of funding. ${ }^{149}$ Coupled with an increasingly mobile student population numbering about half a million individuals capable of claiming equal treatment both as regards access to education and study facilitating benefits, concern with regard to the direction and size of student flows seems at least prima facie justified. As such, the question whether Member States can invoke undue pressure on their public finances as a ground for justification for the imposition of, for example, differential tuition fees (to limit the influx of foreign students) or attaching restrictive conditions to portable study grants (to limit the circle of beneficiaries of such grants, or to enforce the

\footnotetext{
${ }^{144}$ See eg P Hilpold, 'Hochschulzugang und Unionsbürgerschaft' (2005) 21 EuZW 647, 652.

145 Key Data on Education in Europe (EACEA P9 Eurydice, 2012) 87-88.

146 Calculated from GDP data. Eurostat - Tables, Graphs and Maps Interface (TGM) <http:// epp.eurostat.ec.europa.eu/tgm/refreshTableAction.do;jsessionid=9ea7d07d30db67510c7e 4c7c4049b1dff3ee9bbfcd7b.e34MbxeSaxaSc40LbNiMbxeNaxuSe0?tab=table\&plugin=1\&p code $=$ tec00001\&language $=$ en $>$ accessed 2 November 2013.

147 See Eurostat - Data Explorer <http://appsso.eurostat.ec.europa.eu/nui/show. do?dataset=educ_enrl5\&lang=en $>$ accessed 2 November 2013.

148 Key Data on Education in Europe (n 145) 91-92.

149 ibid 93ff.
} 
return of students after their studies abroad) warrants serious consideration. ${ }^{150}$

\subsection{The case against}

It is an accepted truth that 'economic justifications' are rejected at the outset by the Court as incapable of constituting 'pressing reasons of public interest justifying a restriction of a fundamental freedom guaranteed by the Treaty'. ${ }^{151}$ This is not surprising, as such attempts at derogation or justification go against the very core of the functioning and establishment of the internal market: free/unrestricted movement of the factors of production leads (in the long term) to an optimal allocation of scarce resources, boosting economic efficiency and in turn impelling greater consumer welfare; measures that seek to restrict free movement for economic reasons may lead to short-term gain for the Member State imposing them, but overall a 'dead weight loss' of welfare occurs.

However, this internal market ideal is premised on the free movement of production factors, that is to say (in this context), mobile economically active persons (eg workers responding to an offer of employment in another Member State). In contrast, student mobility is at least initially an example of mobility of EU citizens sec, with no or only a limited economic nexus. Notwithstanding this, the contribution of student mobility to the economies of both the 'sending State' and of the 'hosting State', as well as the EU economy as a whole, is significant and should not be underestimated. There is thus a certain economic logic to promoting student mobility, not as a luxury in good times, but as a necessity to promote economic growth in good and bad times.

To see this, it is necessary to explain some of the dynamics underlying endogenous growth theory, which emphasises economic growth as a function of a virtuous cycle of and interaction between human capital, ${ }^{152}$ innovation and knowledge/technology. ${ }^{153}$ This theory suggests

\footnotetext{
150 The focus here is on economic arguments for and/or against student mobility. It should be recognised, however, that student mobility may also have a wide range of other benefits, such as a strengthened sense of European identity and citizenship, mutual learning and cultural exchange. See the Report of the High Level Expert Forum on Mobility, June 2008 <http://ec.europa.eu/education/doc/2008/mobilityreport_en.pdf > accessed 2 November 2013. It is beyond the scope of this paper to discuss these elements in detail.

${ }^{151}$ Case C-109/04 Karl Robert Kranemann v Land Nordrhein-Westfalen [2005] ECR I-2421 para 34.

${ }^{152}$ Human capital in this context refers to the stock of knowledge, skills and attributes (innate or acquired through formal and informal learning processes) that affect productivity as a means to produce economic value: K Dae-Bong, 'Human Capital and its Measurement' ( $3^{\text {rd }}$ OECD World Forum on Statistics, Knowledge and Policy, Korea 37-30 October 2009) 1-4 <http://www.oecd.org/site/progresskorea/44109779.pdf> accessed 2 November 2013. 153 See for the main proponents of this theory P Romer, 'Idea Gaps and Object Gaps in Economic Development' (1993) 32 Journal of Monetary Economics 543; R Lucas, 'On the
} 
that greater educational attainment and skills training is beneficial for the individual, industries and the (national) economy as a whole as its boosts productivity and brings with it a range of positive externalities. This holds true in particular for tertiary education attainment: there is a broad body of evidence that shows an association between tertiary education and labour productivity, higher wages and lower risk of unemployment; ${ }^{154}$ at industry level, the skills level of the work force was also found to be determinative in increasing output per worker ${ }^{155}$ and, finally, at the macro level, the OECD Education at a Glance 2012 EU Country Note finds that $2 / 3$ of GDP growth in 21 EU countries is due to (the income growth of) individuals possessing tertiary qualifications. ${ }^{156}$ Moreover, in terms of positive externalities, the literature suggests that highly skilled workers contribute to innovation and technology adoption which increases the productivity of other workers and physical capital innovation processes associated with highly skilled workers. ${ }^{157}$ Overall, it seems relatively clear that tertiary education attainment in the EU is a crucial factor for future economic development and economic growth. The question remains, however, what student mobility contributes in this regard. It does so, arguably, in two related ways.

Mechanics of Economic Development' (1988) 22 Journal of Monetary Economics 3; J Mincer, Schooling, Experiences and Earnings, (Columbia University Press 1974); and G Becker, Human Capital: A Theoretical and Empirical Analysis, with Special Reference to Education (University of Chicago Press 1993) 15ff. For some initial empirical evidence to support this, see J Barro, 'Economic Growth in a Cross Section of Countries' (1991) 106(2) Quarterly Journal of Economics 407.

${ }^{154}$ A Chevalier et al, The Returns to Higher Education Teaching (Centre for the Economics of Education, 2002) 38-55 <http://cee.1se.ac.uk/pubs/The_Returns_to_Higher_Education_Teaching.pdf> accessed2 November 2013; C Harmon et al, "The Returns to Education: Microeconomics' (2003) 17(2) Journal of Economic Surveys 115; and OECD Education At A Glance (OECD Publishing 2012) 118-161.

${ }^{155} \mathrm{R}$ Wilson and G Briscoe, 'The Impact of Human Capital on Economic Growth: A Review in P Descy and M Tessaring (eds), Impact of Education and Training, Third Report on Vocational Training Research in Europe: Background Report (CEDEFOP Reference Series 542004 ) 35-36; and F Scherer and K Hue, 'Top Managers' Education and R\&D Investment' (1992) 21(6) Research Policy 507.

156 OECD Education at a Glance 2012: OECD Indicators Country Note - European Union 1-3 <http://www.oecd.org/education/EAG2012\%20-\%20Country\%20note\%20-\%20European\%20Union.pdf> accessed 2 November 2013.

157 See R Lucas, 'On the Mechanics of Economic Development' (1988) 22 Journal of Monetary Economics 3, 39; N Stokey, 'Human Capital, Product Quality and Growth' (1991) 106(2) Quarterly Journal of Economics 587, 587-588, 627. See eg P Romer 'Endogeneous Technological Change' (1990) 98(5) Journal of Political Economy 871; and J Vandenbussche et al, 'Growth, Distance to Frontier and Composition of Human Capital' (2006) 11(2) Journal of Economic Growth 97. See further, P Aghion et al, The Causal Impact of Education on Economic Growth: Evidence from the United States' (Brookings Papers on Economic Activity 2009) 4, 33-39 <http://www.brookings.edu/economics/bpea/ /media/ Files/Programs/ES/BPEA/2009_spring_bpea_papers/2009_spring_bpea_aghion_etal.pdf $>$ accessed 2 November 2013. 
The first is the allocation argument. It runs as follows: in the classic economic sense, a rational (prospective) student engages in a cost/ benefit analysis when deciding how much education to obtain. On one side of the scale lie the costs of studying, ranging from having to pay tuition fees, ensuring availability of subsistence resources and the opportunity costs of studying, but also less quantifiable costs such as, for example, the mental effort expended. On the other side are the benefits incentivising greater skills acquisition: the wage premium attached to highly skilled vocations and other factors mentioned above (eg lower risk of unemployment), the (possible) pleasure derived from studying and/or the increased quality of life that is linked with higher educational attainment. ${ }^{158}$ In this model, the student will continue to obtain education to the point where the marginal benefit of obtaining one more year of higher education equals the marginal cost. ${ }^{159}$

Within an increasingly integrated EU internal market, such cost-benefit analysis arguably no longer takes place solely with reference to the national education and labour market; rather, a student may look for a new optimum, taking into account the relative shortage of skills abroad (and thus, for example, the higher wage premium, work opportunities and possibility for career development) or the availability of better quality or better matching (to the cognitive ability of the individual) education abroad. At the same time, other costs relating specifically to foreign studies such as regulatory barriers (eg non-recognition of degrees), the financial costs of moving or the emotional costs of leaving friends and family are also weighed in. ${ }^{160}$ It follows that an important factor in the decision to study abroad is thus the attractiveness of the foreign labour market. As such, the allocation argument sees student mobility as an important predictor of (future) highly skilled migration: ${ }^{161}$ the choice to study abroad is influenced by the desire to work abroad. Thus, by promoting student mobility, the (regional) allocation of highly skilled individuals in the EU is optimised, leading to efficient use of present skills. Moreover, it also boosts, indirectly, incentives for greater skill attainment both because the return on skills attainment abroad may be higher and because the

\footnotetext{
158 W McMahon, Higher Learning, Greater Good (John Hopkins University Press 2009) 42, $43,51,69 f f$.

159 Barr furthermore argues that the aggregate decision-making of students deciding on whether and how much tertiary education to obtain leads to an efficient outcome for society as the market conditions necessary for decentralised decision-making hold true. See N Barr, Economics of the Welfare State (OUP 2012) 301-302, 305-307, 328-329.

${ }^{160}$ See also D Guellec and M Cervantes, 'International Mobility of Highly Skilled Workers: From Statistical Analysis to Policy Formulation' in OECD International Mobility of the Highly Skilled (OECD Proceedings, 2001) 79-83, who discuss the 'pull and push' factors affecting highly skilled migration flows.

${ }^{161}$ Student migration as a channel for highly skilled migration is relatively well established in the literature: K Tremblay, 'Academic Mobility and Immigration' (2005) 9 Journal of Studies of International Education 196, $201 \mathrm{ff}$.
} 
student will need to distinguish himself in order to be competitive in the host labour market. ${ }^{162}$

This is also borne out in practice. There is a broad range of studies which find that mobile students are more likely to work abroad and that the host Member State can thus benefit from a relatively high 'conversion rate' (student-to-worker). ${ }^{163}$ The benefit thereof should not be underestimated: a recent study carried out by the Dutch Central Planning Agency found that foreign EU students in the Netherlands (a net recipient country, see below) generated an estimated net benefit of $€ 652$ million a year to public finances as a result, primarily, of students staying to work after their studies. ${ }^{164}$ As such, the 'free-rider' argument frequently invoked by Member States, whereby mobile students are depicted as locusts who merely consume education in the host State without contributing to the maintenance thereof, seems unjustified. At the same time, it should be stressed that there seems to be no evidence of brain drain: the Member State of origin can also benefit, inter alia, through the formation of business and academic networks, remittances, return of students after a period abroad with new skills, and induced higher skill attainment. ${ }^{165}$ A healthy 'brain circulation'166 thus seems to take place within the EU, egged on by student mobility.

A second argument is the value added or enrichment role of student mobility. Rather than merely functioning as a facilitator or chain in highly skilled migration, student mobility may generate certain benefits all of itself:

\footnotetext{
${ }^{162}$ See generally for the benefits of ensuring optimal allocation of the (highly skilled) workforce of the EU through the mechanisms of free movement: H Bonin et al, 'Geographic Mobility in the European Union: Optimising its Social and Economic Benefits' (IZA Research Report No 19,2008$)$ 52-60.

${ }^{163} \mathrm{U}$ Teichler and V Jahr, 'Mobility During the Course of Study and After Graduation' (2001) 36(4) European Journal of Education 443, 456-457. See for further development of this study: H Schomburg and U Teichler, Higher Education and Graduate Employment in Europe: Results from Graduate Surveys from Twelve Countries, (Springer 2006) 49-50, 77-78, 119-128. See also M Parey and F Waldinger, 'Studying Abroad and the Effect on International Labour Market Mobility: Evidence from the Introduction of Erasmus' (2010) 121 The Economic Journal 194, 217ff; and H Oosterbeek and D Webbink, 'Does Studying Abroad Induce a Brain Drain?' (2011) 78 Economica 347, 361-364.

${ }^{164}$ Calculated from CPB Notitie of 18 April 2012, The economische effecten van internationalisering in het hoger onderwijs, Report for the Ministry for Education, Culture and Science 32 <http://www.rijksoverheid.nl/bestanden/documenten-en-publicaties/rapporten /2012/05/16/de-economische-effecten-van-internationalisering-in-het-hoger-onderwijs/de-economische-effecten-van-internationalisering-in-het-hoger-onderwijs.pdf> accessed 2 November 2013.

${ }^{165}$ See for an overview F Docquier and H Rapoport, 'Globalization, Brain Drain and Development' (IZA Discussion Paper No 5590, 2011).

166 See further: J Salt, 'International Movement of the Highly Skilled' (1997) OECD Occasional Paper No 3 5, 23-25; L Ackers, 'Moving People and Knowledge: Scientific Mobility in the European Union' (2005) 43(5) International Migration 99, 100-101, $120 \mathrm{ff}$.
} 
1. The main argument in this respect is that mobile students may perform better than non-mobile students in an increasingly globalised labour market. This is so in part because there is a strong correlation between student mobility and the propensity to engage in advanced study (an increase in the quantity of education and thus human capital accumulation/skill levels) ${ }^{167}$ and in part because study abroad also adds an extra quality dimension to the educational attainment: such students benefit from having experienced more than one educational and cultural tradition engendering the need for greater adaptability/flexibility and develop a range of soft skills such as language skills, cultural sensitivity and a degree of independence which is linked to greater creativity and innovation processes. ${ }^{168}$

2. Secondly, there is the argument that a mobile student population with the rights of equal treatment as regards access to higher education institutes and (under certain circumstances) access to study grants (either from the home or host Member State) creates competitive pressures on universities. These universities now have to compete not only with universities within that Member State, but also with those located in other Member States for the EU talent pool as a whole. This pushes universities to utilise their resources efficiently, engage in processes of internationalisation and quality improvement ${ }^{169}$ and increase investment in research activities in order to improve their reputation and ranking with a view to attract high potentials. ${ }^{170}$ These processes then benefit both foreign and domestic students.

Overall, therefore, there seem to be good reasons, similar to those that apply to the free movement of the factors of production that is the

\footnotetext{
${ }^{167}$ See O Bracht et al, 'The Professional Value of ERASMUS Mobility' (2006) Final Report to the Commission - DG Education and Culture xiv <http://ec.europa.eu/education/erasmus/doc/publ/evalcareer.pdf>; U Teichler and K Janson, 'The Professional Value of Temporary Study in Another European Country: Employment and Work of Former ERASMUS Students' (2007) 11 Journal of Studies in International Education 486, 488-492.

168 Bracht (n 167) chs 3-5 and $211 \mathrm{ff}$; and J Ritzen and G Marconi, 'Internationalization in European Higher Education' (2011) 3(2) International Journal of Innovation Science 83, 89-90. See also V Papatsiba, 'European Higher Education Policy and the Formation of Entrepreneurial Students as Future European Citizens' (2009) 8(2) European Educational Research Journal 189, 190-192.

169 See S Reichert and C Tauch, 'Trends IV: European Universities Implementing Bologna' (EUA Publications 2005) 28-33; A Sursock and H Smidt, 'Trends 2010: A Decade of Change in European Higher Education' (EUA Publications 2010) 72ff; and P Altbach and U Teichler, 'Internationalization and Exchanges in a Globalized University' (2001) 5(1) Journal of Studies in International Education 5.

${ }^{170}$ L Mechtenberg and R Strausz, 'The Bologna Process: How Student Mobility Affects Multi-cultural Skills and Educational Quality' (2008) 15 International Tax and Public Finance 109, 109-112, 123-125; and M Delpierre and B Verheyden, 'Student and Worker Mobility under University and Government Competition' (2011) CESifo Working Paper No 3415, 2-3.
} 
basis for the establishment of the common market, why economically inspired justifications should continue to be rejected where these impede student mobility. Such obstacles cast their shadow forward and impede the mobility of the highly skilled in the European Union in response to shifting demand patterns, forsake knowledge attainment and the acquisition of important skills that could be obtained by students who are mobile, thereby hampering innovation and economic integration processes, and remove competitive constraints from universities and therewith the benefits that such competition could engender.

\subsection{The case for}

Since student mobility contributes to generating economic growth for the Member States involved and the EU as a whole, the case for a restriction of student mobility on economic or budgetary grounds is a difficult one to make. However, while the benefits may be universal, the burden of shouldering the costs of student mobility is unevenly divided due to the application of general principles regarding the rights of free movement and equal treatment of students to differently situated Member States. The first main variable to consider in this regard is the relative burdens of the net receivers versus the net senders: ${ }^{171}$

\begin{tabular}{|l|l|l|l|l|}
\hline & $\begin{array}{l}\text { Inflow of } \\
\text { students } \\
\text { from } \\
\text { EU-27, } \\
\text { EEA and } \\
\text { candidate } \\
\text { countries } \\
\text { (x1000) }\end{array}$ & $\begin{array}{l}\text { Outflow of } \\
\text { students, } \\
\text { studying in } \\
\text { another EU- } \\
\begin{array}{l}27, \text { EEA, or } \\
\text { candidate } \\
\text { country } \\
\text { (x1000) }\end{array}\end{array}$ & $\begin{array}{l}\text { Net inflow/ } \\
\text { outflow. Positive } \\
\text { number indicates } \\
\text { net receiver } \\
\text { within EU } \\
\text { context; negative } \\
\text { number net } \\
\text { sender (x1000). }\end{array}$ & $\begin{array}{l}\text { Net inflow/ } \\
\text { outflow of } \\
\text { foreign students } \\
\text { as a percentage } \\
\text { of students } \\
\text { in tertiary } \\
\text { education in the } \\
\text { host State }\end{array}$ \\
\hline $\begin{array}{l}\text { EU (27 } \\
\text { countries) }\end{array}$ & & & & \\
\hline Belgium & 35.1 & 10.6 & 24.5 & $5.5 \%$ \\
\hline Bulgaria & 7.8 & 24.5 & -16.7 & $-5.8 \%$ \\
\hline Czech Republic & 25.9 & 12.2 & 13.7 & $3.1 \%$ \\
\hline Denmark & 17.6 & 5.5 & 12.1 & $5 \%$ \\
\hline Germany & 129.7 & 92.2 & 37.5 & $-2.6 \%$ \\
\hline Estonia & 2.1 & 3.9 & -1.8 & $-7.4 \%$ \\
\hline Ireland & 10.3 & 24.7 & -14.4 & $-2.8 \%$ \\
\hline Greece & 15.3 & 33.5 & -18.2 & $0.4 \%$ \\
\hline Spain & 27.6 & 19.3 & 8.3 & $-0.25 \%$ \\
\hline France & 46.3 & 51.8 & -5.5 & $-7.5 \%$ \\
\hline Italy & 16.8 & 46.7 & -29.9 & -23.8 \\
\hline Cyprus & 1.9 & 25.7 & & \\
\hline
\end{tabular}

${ }^{171}$ Data used for calculations obtained from EUROSTAT 2010 values of tps00064 and tps00062 <http://epp.eurostat.ec.europa.eu/portal/page/portal/education/data/main tables> accessed 2 November 2013. 


\begin{tabular}{|l|r|r|r|r|}
\hline Latvia & 0.7 & 5.3 & -4.6 & $-4.1 \%$ \\
\hline Lithuania & 0.3 & 10.5 & -10.2 & $-5.1 \%$ \\
\hline Luxembourg & 2.3 & 7.4 & -5.1 & $-94 \%$ \\
\hline Hungary & 11.0 & 9.0 & 2 & $0.5 \%$ \\
\hline Malta & 0.0 & 2.2 & -2.2 & $-0.5 \%$ \\
\hline Netherlands & 36.0 & 14.9 & 21.1 & $3.2 \%$ \\
\hline Austria & 52.1 & 12.8 & 39.3 & $11.2 \%$ \\
\hline Poland & 5.4 & 33.9 & -28.5 & $-1.3 \%$ \\
\hline Portugal & 3.8 & 19.8 & -16 & $-4.2 \%$ \\
\hline Romania & 3.9 & 40.0 & -36.1 & $-3.6 \%$ \\
\hline Slovenia & 1.4 & 2.6 & -1.2 & $-1 \%$ \\
\hline Slovakia & 7.1 & 31.5 & -24.4 & $-10.4 \%$ \\
\hline Finland & 3.8 & 8.6 & -4.8 & $-1.6 \%$ \\
\hline Sweden & 12.8 & 15.4 & -2.6 & $-0.6 \%$ \\
\hline $\begin{array}{l}\text { United } \\
\text { Kingdom }\end{array}$ & 186.4 & 14.5 & 171.9 & $6.9 \%$ \\
\hline
\end{tabular}

It should not surprise us that many of the 'usual suspects' in student mobility cases correspond to the largest net receivers of students in the European Union. The relatively crude calculation done above gives no indication as to the regional spread or the spread across different courses. As such, there may be something in the bumbling attempts of Belgium and Austria in seeking to limit access to education and the Netherlands and Germany in attempting to circumscribe the group of eligible students for study facilitating benefits in the various cases having come before the Court of Justice. At the same time, quite a few Member States (eg Bulgaria, Ireland, Portugal, Slovakia, as well as Luxembourg and Cyprus) have a large outflow of students. These Member States may, on the one hand, benefit doubly as they gain from the economic benefits set out above and can free-ride on the higher education infrastructure of other Member States. On the other hand, however, at least in the short run, these Member States may be concerned that the mobile students who are provided with mobility grants do not always return from their studies abroad.

A second important variable is the different approaches to the financing and organisation of the higher education systems in the Member States of the EU. These can, arguably, be grouped as points on a scale clustered around three different conceptions of the student enrolled in tertiary education.

At one end we have the 'student as investor'. ${ }^{172}$ This conception is modelled on the idea that the market is the main (decentralised) organiser and financer of the higher education system and guides the decision-ma-

${ }^{172}$ S Schwarz and M Rehburg, 'Study Costs and Direct Public Student Support in 16 European Countries -Towards a European Higher Education Area?' (2004) 39 European Journal of Education 521, 531. 
kers at the points of supply (the higher education institutes) and demand (the student) towards an efficient outcome. Producer and consumer sovereignty is key. Producers, in addition to academic freedom, should be accorded economic freedom which does justice to the heterogeneity of higher education institutes and the courses that they offer (eg higher quality, higher tuition fees, more diverse courses, medical studies subjected to higher tuition fees than accounting). ${ }^{173}$ As such, this system is characterised by relatively high tuition fees covering the full costs (including a profit margin) of providing the student with an education. Similarly, at the demand side, individuals are assumed to act as rational consumers: individuals choose how much and what kind of education to obtain based on an optimisation of an individual utility function. The role of the state is primarily to provide financing options for the student in this regard, as the market for study loans suffers from adverse selection (banks would tend to choose rich students over poor, future accountants over musicians, etc) leading to inefficient outcomes. ${ }^{174}$

In the student-as-investor models, the State usually provides (generous) student loans covering tuition fees, maintenance etc, which are financed either through a graduate tax (all students having completed tertiary education pay a tax premium - a pay-as-you-go system) or income contingent loans (whereby a percentage of the income after graduation goes to the repayment of the individualised loan. Once the loan is repaid, the payment into the system stops - a so-called fully-funded system). ${ }^{175}$ The organisational set up of higher education in England, as part of the UK, come closest to implementing this system: tuition fees are high and practically cover the cost of the student's studies, ${ }^{176}$ but general loans are available, covering both tuition fees and subsistence, subject to a (modified) system of income contingent repayment. ${ }^{177}$ As a result and unlike the general trend in the EU, private resources make up the largest component of tertiary education financing: only some $30 \%$ comes from the public purse. ${ }^{178}$ It follows that the burden of foreign students studying

\footnotetext{
${ }^{173}$ N Barr, The Welfare State as Piggy Bank: Information, Risk, Uncertainty, and the Role of the State (OUP 2001) 192-193.

${ }^{174}$ See M Friedman, 'The Role of Government in Education' in R Solo (ed), Economics and the Public Interest (Rutgers University Press 1955).

175 See generally ibid, chapter 12 .

176 See generally P Bolton, 'Higher Education in England from 2012: Funding and Finance' (2013) SN/SG/6206 House of Commons Library. See in addition P Bolton, 'Tuition Fee Statistics' (2013) SN/SG/917 House of Commons Library.

177 See part 4-6 of The Education (Student Support) Regulations 2011, 2011/1986. See further <http://www.studentloanrepayment.co.uk/portal/page?_pageid=93,6678408\&_ dad=portal\&_schema=PORTAL $>$ accessed 2 November 2013.

178 Data obtained from Education at a Glance 2012 (n 154) Indicator B3 < http://www.oecdilibrary.org/education/education-at-a-glance-2012/indicator-b3-how-much-public-and-private-investment-in-education-is-there_eag-2012-18-en> accessed 2 November 2013.
} 
at educational institutes in England in terms of (non-recoverable) public expenditure is limited, notwithstanding the great numbers of foreign students studying there: students pay their own way.

At the other end of the spectrum, we have the concept of the student as 'good citizen'. ${ }^{179}$ Here the State is the main organiser and financer of the higher education system, and education is seen as just one of the services that the State provides. It is a homogeneous system in that both the higher educational institutes and the courses that they offer are treated as equal (with no greater financing for 'high quality' institutes but rather financing based on performance in terms, for example, of graduation rates and research output $\left.{ }^{180}\right) .{ }^{181}$ The higher education system, rather than being market-oriented, is primarily seen as a method to affect social change and equality, to promote personal development by engaging the (latent) abilities, skills and cognitive resources of individuals, to educate a generation capable of independent thought and forming well-informed viewpoints, to ensure their preparedness for participation in a dynamic and complex society and, finally, to promote participation in and development of the cultural, civil and political community. ${ }^{182}$ The accessibility of higher education to all is of primary importance as a way to mould students into productive, active and engaged members of society.

The system is characterised by low or non-existent tuition fees and generous student support in the form of grants supplemented with lowinterest loans. The Scandinavian countries are usually considered the 'founding members' of this tradition and this is reflected in the proportion of the tertiary education financed by public resources: in Denmark, Finland and Sweden, the State contributes respectively 95.4\%, 95.8\% and $89.8 \%$ of the costs of financing tertiary education. ${ }^{183}$ Looking more closely at Denmark, we see that its high proportion of public funding is the result of a tuition-free higher education system for EU/EEA and Swiss nationals, combined with a generous mixed grant (up to 5753 Danish Krona per month not subject to repayment) and loan system (up to 2943 Krona per month) for maintenance support of the student. ${ }^{184}$ It stands to reason

\footnotetext{
179 Schwarz and Rehburg (n 172) 531.

180 See eg the situation in Sweden: <http://www.hsv.se/densvenskahogskolan/universitetochhogskolor/finansiering.4.539a949110f3d5914ec800063852.html> accessed 2 November 2013 .

181 Barr (n 173) 192-193.

182 See the policy goals underlying the revision of the Swedish Studiestödslag 1999:1395: Proposition 1999/2000:10, 65.

183 Data obtained from Education at a Glance 2012 (n 154) Indicator B3 < http:/ /www.oecdilibrary.org/education/education-at-a-glance-2012/indicator-b3-how-much-public-and-private-investment-in-education-is-there_eag-2012-18-en> accessed 2 November 2013.

${ }^{184}$ In addition, some other grants are made available for, eg, students with children. See chapter 3 Bekendtgørelse af lov om statens uddannelsesstøtte LBK 2009/661 and <http:/ /
} 
that, unlike the system in England, the equal treatment rights that EU nationals can derive from EU law both as regards access to education and as regards study facilitating benefits weigh more heavily on the public purse in countries adhering to this model than in the 'student-as-investor' model. As such, the influx of foreign students in Denmark, as seen above, can be seen as comparatively more pressing than in the UK. ${ }^{185}$

The last model is the 'student-as-child' approach which takes the middle way. Here the primary responsibility for ensuring the education of the student lies with the family unit. For that purpose, the family unit is expected to draw on its own income obtained from the market, although State support is available to supplement the income of those not able to afford the education of their children. ${ }^{186}$ In addition, the State is also tasked with managing the higher education system. There are different gradations within this model, with the student being primarily treated as child who, while studying, lives at home, versus one where the student is more independent but is still considered part of the family unit. Schwarz and Rehburg see this model as the most widespread one, covering western, central and southern Europe. ${ }^{187}$

On the supply side, the State provides most of the financing, and higher education institutes are usually treated homogeneously (with financing primarily tied to the number of students, courses offered and, for universities, research output in the form of doctoral students and publications). ${ }^{188}$ Tuition fees are usually limited in nature and set for all institutes in a universal fashion; student support is generous, albeit dependent on the income of the family. The setup in the Flemish Community of Belgium is a good example of this tradition: low tuition fees (some $€ 600^{189}$ ) combined with student support that varies based on the income of the 'family unit'. ${ }^{190}$ Those students receiving study grants also pay a

www.su.dk/SU/satserSU/videregaaende/Sider/default.aspx> accessed 2 November 2013. A comparison, in Euros, of the study grants systems of the Nordic countries made by the Social Insurance Institution of Finland can be found here < http:/ /www.kela.fi/in/internet/ liite.nsf/alias/nordstod/\$File/nordstod.pdf?OpenElement> accessed 2 November 2013.

185 In fact, the Danish political world is considering cutting the generous system as the costs for maintaining the current system are increasingly becoming unaffordable. See <http:// www.sydsvenskan.se/danmark/politikerna-vill-banta-generost-studiestod/> accessed 2 November 2013.

186 See also the explicit reference to this tradition on the website of the Austrian study grant authority: <http://www.stipendium.at/studienfoerderung/studienbeihilfe/allgemeines / > .

187 Schwarz and Rehburg (n 172) 531.

188 See, eg, the approach in the Flemish Community of Belgium: Article 9ff of the Decreet betreffende de financiering van de werking van de hogescholen en de universiteiten in Vlaanderen, Belgisch Staatsblad 2008, 32820.

189 See page 3 of the brochure Studiegelden academiejaar 2013-2014<http://www.ond. vlaanderen.be/hogeronderwijs/studeren/studiegelden/studiegelden2013-2014.pdf > accessed 2 November 2013.

190 See Article 5(21) juncto 33 Decreet betreffende de studiefinanciering van de Vlaamse 
lower tuition fee. ${ }^{191}$ More support is given if the student lives on his or her own rather than with the family. ${ }^{192}$ The preparatory documents of the Decree on Study Finance (which integrates support for primary, secondary and tertiary education) reveals that the main goal is indeed to support families on whose budget the education of the children weighs heaviest in order to encourage greater participation at all levels of education. ${ }^{193}$ In terms of the impact of foreign EU students studying in countries adhering to this model, it may be expected to lie between the 'investor' and the 'good citizen' model: tuition fees are low, which means that the 'state subsidy' for each student in higher education is high. ${ }^{194}$ Student support is relatively generous, but not as extensive as in the countries following the Scandinavian model.

\section{Balancing the scales}

Looking at the two sides presented above, it seems justified to conclude that in a general sense Member States' attempts at restricting access to higher education institutes established within their territory or by limiting eligibility for study facilitating benefits (and the export thereof) for economic reasons should be struck down. Free movement of students has its own inherent economic logic that militates against restrictions for economic or budgetary reasons: student mobility forms an important link in the optimal allocation of highly skilled individuals in the EU and also constitutes a crucial learning experience for the student by which he or she becomes a more productive and adaptable worker. Empirics seem to support this overall conclusion. As seen above, a study conducted by the Central Planning Agency of the Netherlands, which is a net receiver of students and which with $72 \%$ public financing of tertiary education takes an intermediate position in the EU, showed a net benefit to the public purse attributed to EU students of some $€ 652$ million a year. While this outcome depends on a number of variables, not the least of which the propensity of students to stay after their studies, one can still expect the benefits to be significant even in Member States with a lower staying rate or a higher degree of public financing. Moreover, as seen, sending States

Gemeenschap Belgisch Staatsblad 2007, 38879. See also <http: / www.ond.vlaanderen.be/ studietoelagen/brochure12-13/toelagenperonderwijsniveau/hogeronderwijs/> accessed 2 November 2013 for an example calculation.

${ }^{191}$ See Article 57 Decreet betreffende de flexibilisering van het hoger onderwijs in Vlaanderen en houdende dringende hogeronderwijsmaatregelen, Belgisch Staatsblad 2004, 71039.

192 See Article 44 Decreet betreffende de studiefinanciering van de Vlaamse Gemeenschap Belgisch Staatsblad 2007, 38879

193 Ontwerp van de Decreet betreffende de studiefinanciering in de Vlaamse Gemeenschap, Parl St V1 Parl 2006-2007, nr 1171/1, 3, 5.

${ }^{194}$ See, eg, the percentages of the proportion of public financing of Belgium, Italy, Greece and Ireland. 
need not worry either as there seems to be no evidence for the oft-invoked spectre of brain drain.

Notwithstanding this general conclusion, it should also be recognised that the 'one size fits all' nature of the principles developed by the Court has a differential impact on some Member States: the financial responsibility or burden of enabling and promoting student mobility is unevenly divided among the Member States. Equal treatment as regards access to education weighs more heavily on, say, Sweden than it does on the United Kingdom (England); similarly, export of study grants is likely to cost the Netherlands more, in a relative sense, than it does in France which only provides limited export support. ${ }^{195}$ Consider further that while the benefit to the public purse as a whole may be large, it is unclear what the net effect is on higher education budgets, specifically in the receiving Member States: how much of the gain is in practice reinvested in higher education? Greater (foreign) student numbers enrolling in higher education institutes without an accompanying increase in spending on higher education will mean that the amount of financing per student drops, which in turn almost certainly has consequences for the quality of education for all students.

Whereas these issues may not yet be so pressing at the moment, it will be recalled that student mobility in the EU is a growing phenomenon and enjoys active support in both the Bologna as well as the EU context. In respect to the latter, the Council has set the goal that by $2020,20 \%$ of all higher education graduates should have had some higher education or related training experience abroad. ${ }^{196}$ As such, the issue can be expected to become more pressing in the future. The question remains about how to address this growing tension between greater student mobility and the financial sustainability of higher education systems. Three approaches may be considered:

1. Maintaining the status quo.

The normative justification for doing so could lie in the concept of EU transnational solidarity. The argument would run that as the European Union grows ever more tightly knit, the narrow weighing of costs and benefits within one sector becomes increasingly inappropriate. The benefits of establishing the internal market, for example, can very well vastly outweigh 'losses' in particular (sub)sectors such as this one. As such, the fact that some Member States contribute more to student mobility than

\footnotetext{
195 See 2012-0029 Modalités d'attribution des bourses d'enseignement supérieur sur critères sociaux et des aides au mérite et à la mobilité international pour l'année 2012-2013 of 19 July 2012: mobility grants are only offered for credit mobility purposes. In contrast, the Netherlands offers full export abroad: Article 2.14 Wet studiefinanciering 2000.

196 Council Conclusions on a benchmark for learning mobility, OJ [2011] C 372/31, 34.
} 
others is, in this view, 'in the grand scheme of things' irrelevant: these Member States are rather required to take this into their stride in view of the benefits they gain elsewhere from European cooperation.

The problem with this (decentralised) approach, however, is that political or budgetary realities may be such that these Member States are in essence forced to address the mounting pressure on the educational budget and adopt higher education policies that go against their preferred principles of organising their higher education systems. Consider that mobile German and French students put significant pressure on the sustainability of open access systems such as Austria and Belgium. These Member States in turn felt obliged to limit access by means of a quota to seek to manage these flows, whereas both France and Germany retained the freedom to do as they wished. Similarly, as a result of the Court's ruling in Commission $v$ the Netherlands, the Dutch government put a funding cap on the export of study grants, notwithstanding its commitment to introducing portable study grants. ${ }^{197}$ In a general sense, with the disparities in financial responsibility for the free movement of students comes a reduced scope for action for some (smaller) Member States: they are caught between a rock (political/budgetary realities) and a hard place (the Court's case law). Others (usually larger Member States), who in some sense can be seen as the 'cause' for mobility flows (eg the numerus clausus systems of France and Germany restricting access to medical courses), remain scot free. This is an undesirable consequence in a policy area, belonging primarily to the Member States, which is intricately tied up with societal values: the freedom of some Member States to organise their higher education system according to their preferred principles must not impinge on the freedom of other Member States to do the same.

\section{Allowing unilateral restrictions.}

A second way to address the tension would be to allow those Member States who can properly substantiate their exceptional 'burden' in enabling and promoting student mobility to maintain the unilateral restrictions they deem necessary to alleviate this burden. The problem with this approach is that it essentially comes down to 'passing the buck': it redirects flows to other Member States who in turn may be faced with an (in their eyes) unmanageable influx of students and will eventually reduce student mobility altogether as students become progressively discouraged by the many barriers existing abroad. As with all forms of 'protectionism', such a system would in the end be self-defeating, and lead to the non-attainment of the mobility goals.

\footnotetext{
197 Brief aan de Tweede Kamer: Reactie op Uitspraak Commissie-Nederland C-542/09 of 15 June 20122012 D25781.
} 


\section{A multilateral solution.}

A third approach would be for the EU legislator to intervene. It is arguable that (the promotion of) student mobility fulfils the requirements of a public good in economic terms: in a globalised and increasingly integrated European Union the benefits generated by student mobility are increasingly non-rivalrous in nature (all Member States may benefit from greater innovation, enhanced productivity etc) and, as a result of the right of free movement among the EU Member States, non-excludable (no Member State can 'retain' the student against his or her will through immigration law). ${ }^{198}$ Economic theory teaches that this is a reason for State intervention. The nature of a public good is such that it provides benefits to all, but all (here the Member States) equally have an incentive not to finance the good precisely for that reason: if 'others' finance the good, the benefits still accrue to the free-rider, leading to advantages at no cost. The result, of course, is that no one is willing to finance the public good.

It should be remarked, however, that the theory does not fully hold for student mobility. Some of the elements that promote such mobility (high quality education, comprehensive study grant systems) are financed by Member States for reasons other than mere economic gain and in any case student mobility is not the foremost consideration in terms of deciding on public expenditure in this regard. However, in general the idea of Member States free-riding in the context of student mobility cannot be excluded, especially with the current uneven division of student flows among the EU Member States (eg Germany 'outsourcing' the training of medical professionals to Austria). As such, there is perhaps scope for EU intervention in this regard, perhaps in the form of an EU reimbursement scheme and/or study loan system.

Following the Erasmus judgment ${ }^{199}$ and the introduction of EU competences in the field of education in Article 165 and 166 TFEU, it seems pretty clear that competence exists at the EU level to set up an EU grant/ loan system for mobility purposes (going beyond credit mobility, which Erasmus focuses on, to funding full study periods abroad): the Treaties refer to the power to adopt incentive measures ${ }^{200}$ for the purposes of pursuing the objectives of EU educational policy, which include student mobility. ${ }^{201}$ This study grant/loan system could have two major components:

1. A State-to-State reimbursement system. This system should operate on the principle that Member States are responsible for their

\footnotetext{
198 See also N Barr et al, 'Feasibility Study on Student Lending' (EAC/47/2009 Report to the European Commission: Directorate-General for Education and Culture 2011) x.

199 Case 242/87 Commission v Council (ERASMUS) [1989] ECR 1425.

200 Article 165(4) TFEU. The same limitation is not apparent in Article 166(4) TFEU.

201 See Articles 165(2) and 166(2) TFEU.
} 
citizens' education and is meant to avoid abuse of the mobility of students: a Member State could conceivably send the majority of its students abroad to receive education, thereby freeing up the resources it would otherwise have to commit towards that individual's education. In order to ensure a degree of fairness and in the light of the great disparity among the Member States in resources committed at the tertiary education level (in particular between the original EU15 and the new EU13), the following principle is suggested. The reimbursement rate as a base determinant should be the real costs borne by the public purse in the host State for the education of a student, but with the upper limit that the reimbursement could not exceed the costs the reimbursing State would bear had the student been educated in the home State. ${ }^{202}$ While this will not lead to full reimbursement in all cases, it seems a fairer system than the current one, where the net recipients bear the greatest costs. Whereas the political feasibility of such a system, especially in the current economic situation, seems somewhat limited, there is an argument to be made that the principle of loyal cooperation found in Article 4(3) TEU requires Member States that are net senders to cooperate with net recipients to find a solution. As shown above, in an internal market characterised by free movement and a presumption in favour of unrestricted student mobility, the educational policies of one Member State directly affect the sustainability of the higher education system in another Member State. In view of these spill-over effects, and in view of the general aim of promoting student mobility, 'sending Member States' can at least to some extent be held responsible for the restrictions introduced by the receiving Member States (eg such as in Bressol). This leads one to question whether these Member States can really refuse to at least consider a reimbursement system in the light of their obligation to 'facilitate the achievement of the Union's tasks and refrain from any measure which could jeopardise the attainment of the Union's objectives' ${ }^{203}$

2. A study loan system available for students exercising their free movement rights to study in another Member State other than their Member State of nationality (and/or their Member State or previous study). A recent study on the feasibility of an EU student lending facility conducted by Barr et al concludes that an EU loan system covering both tuition fee and maintenance cost in the host

\footnotetext{
${ }^{202}$ Similar to the situation in healthcare under the free movement of services provisions, see A Dawes, "Bonjour Herr Doctor": National Healthcare Systems, the Internal Market and Cross-border Medical Care within the European Union' (2006) 33(2) Legal Issues of Economic Integration 167, 170-174.

${ }^{203}$ Article 4(3) TEU.
} 
State (initially for master students only) with repayment based on fixed repayments (a mortgage style loan) imposed on middle to high income individuals and income contingent repayments for low income individuals (scaling with ability to pay) is both desirable and feasible. ${ }^{204}$ The cost of such a system, should one adhere to the goal of ensuring $20 \%$ mobility of (master) students, would not be insignificant: it is estimated that the financing needs would run to $€ 5$ billion a year. ${ }^{205}$ However, it seems quite clear that this figure would be more than offset in terms of benefits for the EU Member States. Both the reduced pressure on national study grant schemes as well as the benefits brought about by greater student mobility more generally ${ }^{206}$ should be more than sufficient to convince the Member States to consider the option. ${ }^{207}$

\section{Conclusion}

Overall, therefore, there seems to be enough room for and even a certain degree of urgency in favour of a broader discussion as regards the future of student mobility in the European Union and the role that the latter may play, beyond the judgments of the Court of Justice, in the promotion thereof. It is submitted here that now this role is underdeveloped in that student mobility is primarily an uncoordinated and unmanaged phenomenon, the principles of which are set out progressively by the Court in its case law. However, in the light of the ever growing number of foreign students seeking access to higher education in a Member State that is not their own, it is time the discussion moved towards more concrete action at the initiative of EU policy makers.

\footnotetext{
${ }^{204}$ Barr (n 198) chapter 5 and 1 . The reason for the distinction between high, middle and low income groups is to ensure the attractiveness and flexibility of the system necessary to attract those interested in borrowing from it.

205 ibid 91.

${ }^{206}$ For further gains of an EU student loan system, including economies of scale and its ability to better manage asymmetric student migration flows, see Barr (n 198) 13-22.

207 The Commission in its Erasmus For All programme favours the adoption of such a system. See Commission, 'Erasmus For All: The EU Programme for Education, Training, Youth and Sport' (Communication) COM (2011) 787 final.
} 